BNL- 72488-2004-IR INFORMAL REPORT

\title{
SUSTAINABLE CONCRETE FOR WIND TURBINE FOUNDATIONS
}

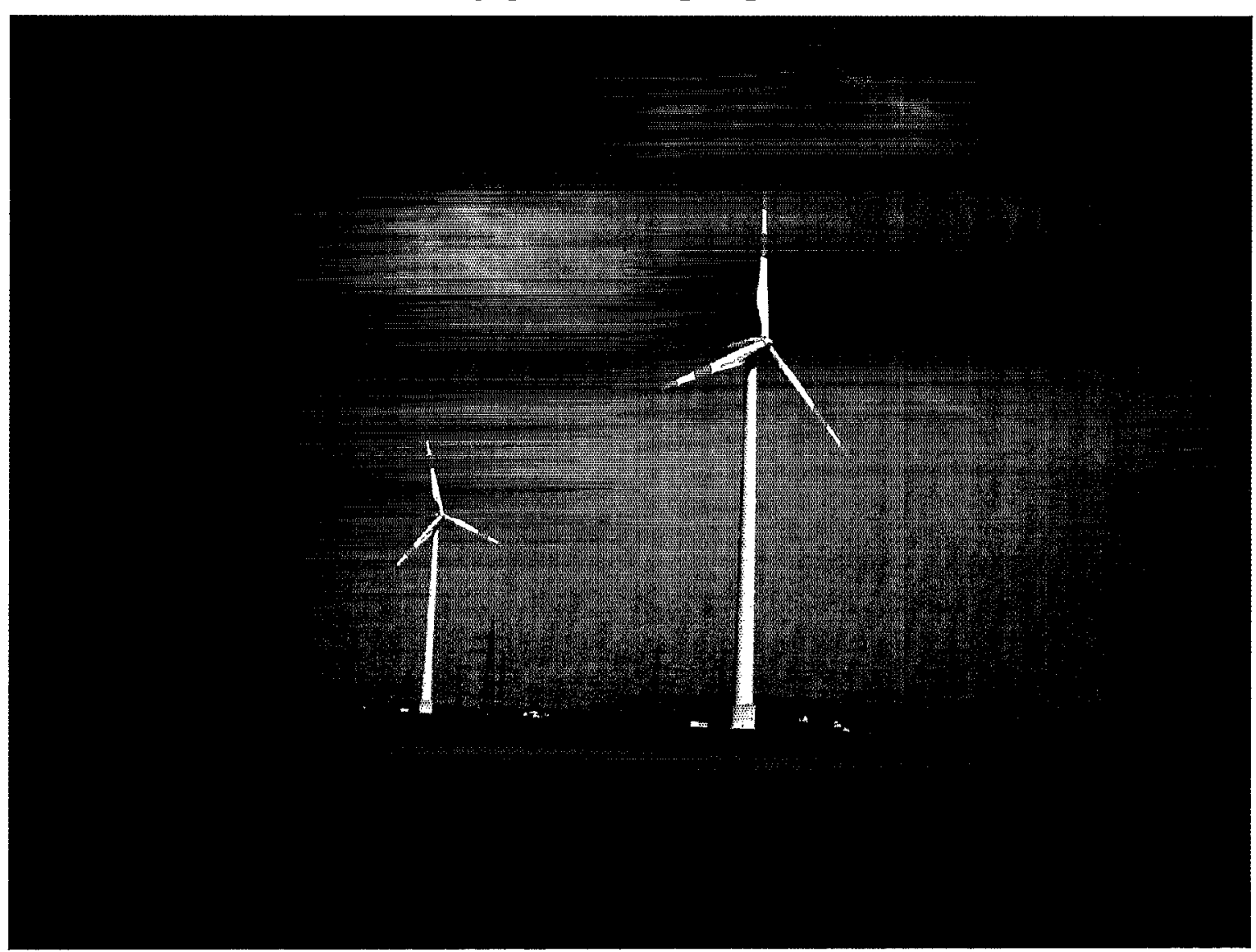

M.L. Berndt

June 2004 
SUSTAINABLE CONCRETE FOR WIND TURBINE FOUNDATIONS

M.L. BERNDT

JUNE 2004

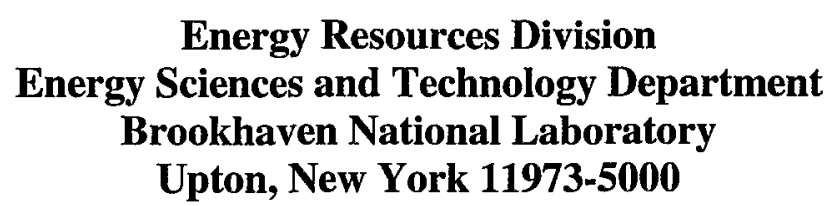

This work was performed under the auspices of the U.S. Department of Energy, Washington, D.C., under Contract No. DE-AC02-98CH10886. 


\section{DISCLAIMER}

This document was prepared as an account of work sponsored by an agency of the United States Government. Neither the United States Government nor any agency thereof, nor any of their employees, nor any of their contractors, subcontractors, or their employees makes any warranty, express or implied, or assumes any legal liability or responsibility of the accuracy, completeness, or usefulness of any information, apparatus, product or process disclosed, or represents that its use would not infringe privately owned rights. Reference herein to any specific commercial product, process, or service by trade name, trademark, manufacturer, or otherwise, does not necessarily constitute or imply its endorsement, recommendation, or favoring by the United States Government or any agency thereof. The views and opinions of authors expressed herein do not necessarily state or reflect the United States Government or any agency, contractor, or subcontractor thereof. 


\section{CONTENTS}

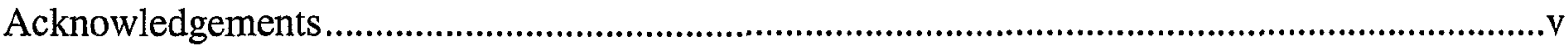

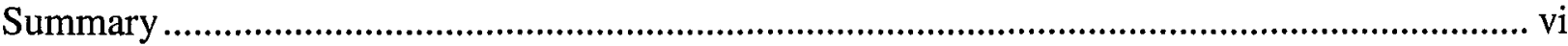

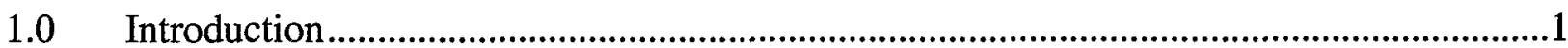

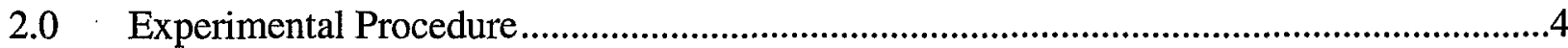

2.1 Materials and Concrete Mix Design .....................................................................

$2.2 \quad$ Mixing Procedure ....................................................................................................

2.3 Compressive Strength ..........................................................................................

$2.4 \quad$ Splitting Tensile Strength ...................................................................................

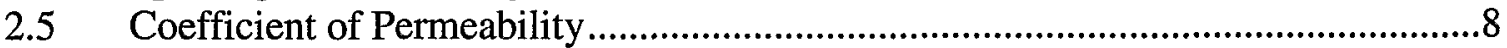

$2.6 \quad$ Elastic Modulus .............................................................................................

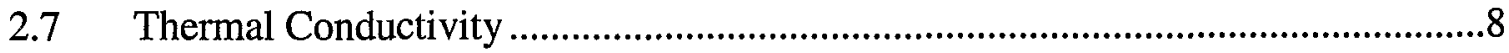

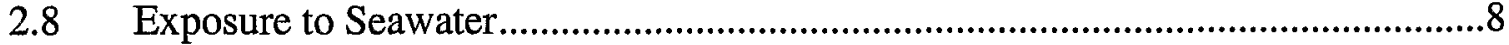

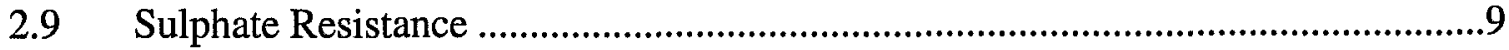

2.10 Polarization Studies on Steel Fibres ................................................................9

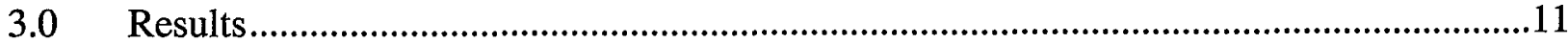

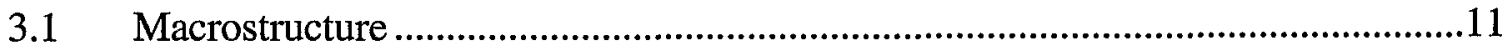

3.2 Compressive Strength ..........................................................................................12

3.3 Splitting Tensile Strength ......................................................................................14

3.4 Coefficient of Permeability ..............................................................................16

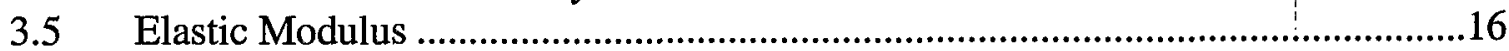

3.6 Thermal Conductivity ...........................................................................................17

$3.7 \quad$ Exposure to Seawater.......................................................................................17

3.8 Sulphate Resistance .........................................................................................18

3.9 Polarization Curves for Fibre Reinforced Concrete...................................................19

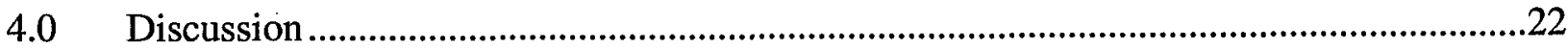

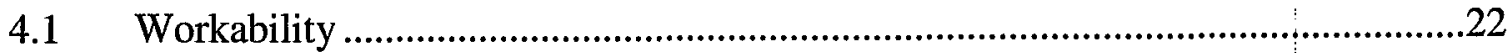

4.2 Compressive Strength ..........................................................................................23

4.3 Splitting Tensile Strength ...................................................................................23

4.4 Coefficient of Permeability .............................................................................24

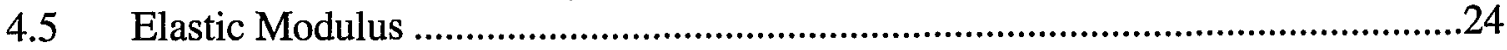

4.6 Thermal Conductivity ..........................................................................................24

$4.7 \quad$ Durability in Seawater .....................................................................................24

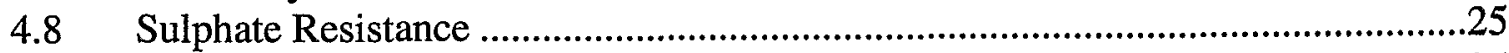

$4.9 \quad$ Polarization Curves......................................................................................25

5.0 Conclusions 


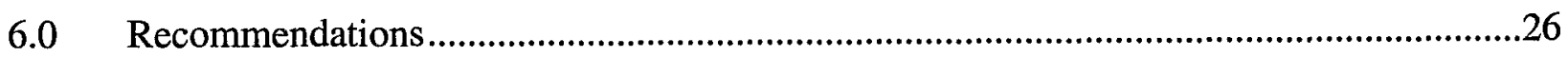

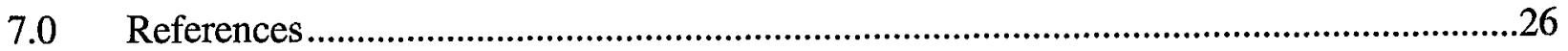




\section{ACKNOWLEDGEMENTS}

This work was performed under a BNL LDRD (Laboratory Directed Research and Development) program. The project was "Dynamics of Wind Turbine-TowerFoundation Systems" and the Principal Investigator was Dr. A.J. Philippacopoulos. The work reported herein describes the materials engineering component of the project. The author thanks Dr. Philippacopoulos for assistance with the concrete mixing and other aspects of the research. 



\section{SUMMARY}

The use of wind power to generate electricity continues to grow, especially given commitments by various countries throughout the world to ensure that a significant percentage of energy comes from renewable sources. In order to meet such objectives, increasingly larger turbines with higher capacity are being developed. The engineering aspects of larger turbine development tend to focus on design and materials for blades and towers. However, foundations are also a critical component of large wind turbines and represent a significant cost of wind energy projects.

Ongoing wind research at BNL is examining two areas: (a) structural response analysis of wind turbine-tower-foundation systems and (b) materials engineering of foundations. This work is investigating the dynamic interactions in wind turbine systems, which in turn assists the wind industry in achieving improved reliability and more cost efficient foundation designs. The results reported herein cover initial studies of concrete mix designs for large wind turbine foundations and how these may be tailored to reduce cost and incorporate sustainability and life cycle concepts.

The approach taken was to investigate material substitutions so that the environmental, energy and $\mathrm{CO}_{2}$-impact of concrete could be reduced. The use of high volumes of "waste" materials in concrete was examined. These materials included fly ash, blast furnace slag and recycled concrete aggregate. In addition, the use of steel fibre reinforcement as a means to improve mechanical properties and potentially reduce the amount of bar reinforcement ị concrete foundations was studied.

Four basic mixes were considered. These were: (1) conventional mix with no material substitutions, (2) 50\% replacement of cement with fly ash, (3) $50 \%$ replacement of cement with blast furnace slag and (4) $25 \%$ replacement of cement with fly ash and $25 \%$ replacement with blast furnace slag. Variations on these mixes included the addition of $1 \%$ by volume steel fibres. The use of recycled concrete aggregate in the conventional and $50 \%$ slag mixes was also studied.

Properties investigated included compressive and tensile strengths, elastic modulus, coefficient of permeability, thermal conductivity and durability in seawater and sulphate solutions. It was determined that the mixes containing 50\% slag gave the best overall performance. Slag was particularly beneficial for concrete that used recycled aggregate and could reduce strength losses. Initial durability results indicated that corrosion of fibres in the different concrete mixes when exposed to seawater was minimal.

Future research needs to include more detailed studies of mix design and properties of concrete for wind turbine foundations. Emphasis on slag-modified mixes with natural and recycled concrete aggregate is recommended. The proportion of slag that can be incorporated in the concrete needs to be optimized, as does the grading of recycled aggregate. The potential for using silica fume in conjunction with slag is worth exploring as this may further enhance strength and durability. Longer-term durability 
studies are necessary and other pertinent properties of concrete that require investigation include damping characteristics, pullout strength, fatigue strength and risk of thermal cracking. The properties of sustainable concrete mixes need to be integrated with studies on the structural behaviour of wind turbine foundations in order to determine the optimal mix design and to examine means of reducing conservatism and cost of foundations. 


\section{SUSTAINABLE CONCRETE FOR WIND TURBINE FOUNDATIONS}

\subsection{INTRODUCTION}

The current trend in power generation from wind is to use turbines of increasing capacity. Large wind turbines (1-2.5 MW capacity) are becoming mainstream and recent developments have seen even larger turbines become a reality, particularly for offshore installations. For example, prototype turbines with capacities of 3.0 MW (Vestas) 3.6 MW (GE Wind Energy), 4.2 MW (NEG Micon) and 4.5 MW (Enercon) are being tested and a 5.0 MW turbine is being developed by Nordex. Large turbines require substantial foundations and associated structural and geotechnical engineering considerations (Bodamer, 1999). The primary purpose of the foundation is to resist the overturning moment. Selection of a foundation design depends on the turbine location and site conditions. Onshore turbines typically use reinforced concrete slab or multi-pile type designs. Examples of these foundations are described by Burton et al. (2001). The dimensions of slab foundations for large onshore turbines depend on the geotechnical conditions and structural requirements. A typical slab foundation for a $1 \mathrm{MW}$ turbine would be approximately $15 \mathrm{~m}$ diameter and $1.5-3.5 \mathrm{~m}$ deep. Turbines in the 1 to $2 \mathrm{MW}$ range typically use 130 to $240 \mathrm{~m}^{3}$ of concrete for the foundation. Multi-pile foundations are used in weaker ground conditions and require less concrete. Annular designs are also gaining in popularity and these consist of two corrugated steel casings with a concrete filled annulus. For a $900 \mathrm{~kW}$ turbine a typical annular foundation would consist of $5.3 \mathrm{~m}$ and $3.6 \mathrm{~m}$ diameter casings buried to a depth of $10 \mathrm{~m}$. Offshore turbine foundation options include concrete gravity, steel gravity, tripod and monopile configurations. Floating platforms are also being considered for offshore wind turbines in deep water.

As turbines become larger, the foundation costs become a significant proportion of the total cost for a wind farm and influence the overall cost of energy. Therefore, foundation design and selection of materials becomes important for economic reasons, in addition to structural and durability aspects. In the case of reinforced concrete foundations, measures can be taken to reduce costs while maintaining function and required service life. The cost of foundations is not only monetary and includes environmental costs that need to be taken into account.

The substantial amount of concrete typically used in foundations for large wind turbines requires a concomitant large amount of cement, in addition to sand and aggregate. Production of cement is energy intensive and involves considerable generation of $\mathrm{CO}_{2}$. In fact, cement production accounts for approximately $8 \% \mathrm{Co}_{2}$ emissions worldwide. It is estimated that $60 \%$ of $\mathrm{CO}_{2}$ emissions from industrial processes in the US are attributable to cement manufacture and that the direct release of $\mathrm{CO}_{2}$ containing 11.4 million tonnes of carbon equivalent into the atmosphere was associated with US cement production in 2001 (Energy Information Administration, 2001). Putting this in another perspective, the manufacture of one tonne of cement releases approximately one tonne of $\mathrm{CO}_{2}$ (Aitcin, 2000). Furthermore, the estimated amount of energy required to produce one tonne of cement in the US in 2001 was $5.36 \mathrm{GJ}$ (Jacott et al., 2003). In addition, significant amounts of steel are required for reinforcing 
concrete foundations. Production of iron and steel is also energy intensive and responsible for 39.9 million metric tons of carbon emissions in the US in 1994 (Energy Information Administration, 1998). The amount of $\mathrm{CO}_{2}$ produced per tonne of steel in the US is approximately 0.55 tonnes based on 1994 data (Kim and Worrell, 2002). Finally, the use of cement, water, steel, sand and aggregate also depletes natural resources.

One of the advantages of operating wind turbines is the reduced emission of $\mathrm{CO}_{2}$ as well as $\mathrm{SO}_{2}$ and $\mathrm{NO}_{\mathrm{x}}$ as compared to other energy sources, such as electricity from coal-fired power stations. It is estimated that typical coal-fired plants in the UK emit 860 $\mathrm{g} \mathrm{CO}_{2} / \mathrm{kWh}, 10 \mathrm{~g} \mathrm{SO}_{2} / \mathrm{kWh}$ and $3 \mathrm{~g} \mathrm{NO}_{\mathrm{x}} / \mathrm{kWh}$ (British Wind Energy Association, 2003 www.bwea.com/edu/calcs.html). For a turbine with a rated capacity of $1.3 \mathrm{MW}$ and a capacity factor of 0.3 , the estimated annual emissions reductions would be 2938 tonnes of $\mathrm{CO}_{2}, 34$ tonnes of $\mathrm{SO}_{2}$ and 10 tonnes of $\mathrm{NO}_{\mathrm{x}}$. However, the $\mathrm{CO}_{2}$ involved in producing the materials required for reinforced concrete foundations also has to be taken into account when considering the emission benefits of wind power. Concrete for structural purposes typically has a cementitious material content of $300-450 \mathrm{~kg} / \mathrm{m}^{3}$, depending on the required strength and durability. Thus, a $240 \mathrm{~m}^{3}$ concrete foundation that does not include any pozzolanic or other supplementary cementitious material for an onshore 1.3 MW turbine may require 72-108 tonnes of portland cement and thereby be responsible for 72-108 tonnes of $\mathrm{CO}_{2}$ prior to turbine operation. If the same foundation contains approximately 10 tonnes of reinforcing steel, then the amount of $\mathrm{CO}_{2}$ also involved is a minimum of 5.5 tonnes. This estimate does not include the $\mathrm{CO}_{2}$ contribution associated with the energy required to convert the steel from an ingot to bar form. It is noted that reinforcement is often produced from recycled steel and this alters the energy- and $\mathrm{CO}_{2}$ intensity.

Minimizing the environmental impact and energy- and $\mathrm{CO}_{2}$-intensity of concrete used for wind turbine foundations is important. Thus, it is logical to use life cycle and sustainable engineering approaches to concrete mix design. This requires several elements: maximizing concrete durability, conservation of materials, use of waste and supplementary cementing materials, and recycling of concrete. Maximization of durability uses best practices to ensure that the structure retains it functionality throughout its service life. Examples of how this may be achieved include minimization of water/cement ratio, appropriate depth of cover to reinforcement, selection of materials and mix design to prevent deleterious reactions in the service environment, avoidance of reactive aggregates, use of admixtures to enhance workability and placement, proper compaction and curing, and use of corrosion mitigation techniques such as cathodic protection. Waste and supplementary cementing materials such as fly ash, blast furnace slag, silica fume, rice husk ash and metakaolin can be used as partial replacements for portland cement. These materials can improve concrete durability, reduce the risk of thermal cracking in mass concrete and are less energy- and $\mathrm{CO}_{2}$-intensive than cement. Aggregate obtained from crushed concrete is an example of how concrete can be recycled and used to conserve materials and reduce waste in landfills. 
Increasing attention is being given to the use of sustainable concepts in concrete construction and these are particularly appropriate for inclusion in the design of foundations for wind turbines. Examples of recent developments in sustainable philosophies are given by Aïtcin (2000) Mehta (2000, 2001, 2002), Ho et al. (2000) and Holland (2002). Much research has been performed on the use of high volumes of fly ash to produce sustainable, durable concrete (e.g., Bilodeau et al. 1994; Malhotra, 1999, 2000, 2002; Malhotra et al., 2000a, b). Recycled concrete is becoming of increasing interest for use as aggregate in structural concrete. Examples of recent research on the properties of concrete containing recycled concrete aggregate include Ahmad et al. (1996), Tavakoli and Soroushian (1996), Salem and Burdette (1998), Sagoe-Crentsil et al. (2001), Gómez-Soberón (2002), Olorunsogo and Padayachee (2002) and Shayan and $\mathrm{Xu}(2003)$.

Recommendations for reinforced concrete used in offshore wind turbine foundations have been developed by the Danish Energy Agency (2001). In addition to minimum depth of cover and maximum crack width guidelines, it is recommended that concrete have a water/cement ratio $<0.4$ and a characteristic compressive strength $>40$ $\mathrm{MPa}$. It is also recommended that the risk of thermal cracking be minimized by keeping temperature differences over cross-sections to be less than $12-15^{\circ} \mathrm{C}$. Cathodic protection of reinforcement is recommended to mitigate corrosion.

The objective of the research described in this report was to assess the suitability of some sustainable concrete mix designs for use as wind turbine foundations. The mixes contained relatively high amounts of fly ash, blast furnace slag and combinations of both. In addition, recycled concrete was studied for use as aggregate. Steel fibre reinforcement was investigated as this has potential to reduce the amount of reinforcing bar in concrete as well as provide improved crack resistance, fatigue strength and other mechanical properties. The mixes were tested for basic mechanical, hydraulic and thermal properties in addition to durability in environments that may be encountered either as partially buried foundations for onshore turbines or seawater exposed foundations for offshore turbines. Optimization of mix proportions would be the subject of future studies. 


\subsection{EXPERIMENTAL PROCEDURE}

\subsection{Materials and Concrete Mix Design}

Concrete mixes containing either natural or recycled concrete aggregates (RCA) were studied and compared. Four different mix designs were investigated for the concrete with natural aggregate. The first of these was a control mix and did not contain any fly ash or ground granulated blast furnace slag. Two of the mixes contained 50\% replacement of cement with either fly ash or slag. The final mix used $25 \%$ fly ash and $25 \%$ slag as cement replacement. The cement used was Type I portland cement. The fly ash was Class F and obtained from Boral. Grade 120 blast furnace slag (Allcem ${ }^{\mathrm{TM}}$ ) was supplied by Lehigh. The silica sand used conformed to ASTM C 33 and the natural coarse aggregate was round, smooth siliceous stone sieved between 6.35 and $12.7 \mathrm{~mm}$. Both the fine and coarse aggregates were oven dried prior to use. Sodium naphthalene sulphonate superplasticizer (Rheobuild 1000) was used to improve concrete workability. Air entrainment was not used at this stage but is recommended for foundations exposed to freeze-thaw conditions. All mixes had a water/cementitious material ratio of 0.4 . The mix proportions, yield and slump are presented in Table 1.

Table 1. Mix Proportions of Concrete with Natural Aggregate

\begin{tabular}{|l|c|c|c|c|}
\hline & 100 OPC & 50 FA & 50 BFS & 25 FA/25 BFS \\
\hline Cement $\left(\mathrm{kg} / \mathrm{m}^{3}\right)$ & 390.4 & 190.3 & 195.4 & 191.0 \\
\hline Fly Ash $\left(\mathrm{kg} / \mathrm{m}^{3}\right)$ & 0 & 190.3 & 0 & 95.5 \\
\hline BFS $\left(\mathrm{kg} / \mathrm{m}^{3}\right)$ & 0 & 0 & 195.4 & 95.5 \\
\hline Water $\left(\mathrm{kg} / \mathrm{m}^{3}\right)$ & 156.3 & 152.4 & 156.5 & 153.0 \\
\hline Sand $\left(\mathrm{kg} / \mathrm{m}^{3}\right)$ & 739.1 & 720.7 & 739.7 & 723.1 \\
\hline Aggregate $\left(\mathrm{kg} / \mathrm{m}^{3}\right)$ & 1118.2 & 1090.3 & 1119.1 & 1094.0 \\
\hline Superplasticizer $\left(1 / \mathrm{m}^{3}\right)$ & 3.90 & 3.81 & 3.91 & 3.82 \\
\hline Yield $\left(\mathrm{kg} / \mathrm{m}^{3}\right)$ & 2405 & 2345 & 2407 & 2353 \\
\hline Slump $(\mathrm{mm})$ & 75 & 170 & 65 & 130 \\
\hline
\end{tabular}

Steel fibre reinforced versions of the above mixes were evaluated. Dramix ${ }^{\circledR} R L$ $45 / 50$ (Bekaert Corporation) hooked end fibres were added to give a volume fraction of $1 \%$. These fibres were round in cross section, $50 \mathrm{~mm}$ long and $1.05 \mathrm{~mm}$ diameter. The fibres are illustrated in Figure 1. Mixes containing fibres are designated by the suffix "FR". 


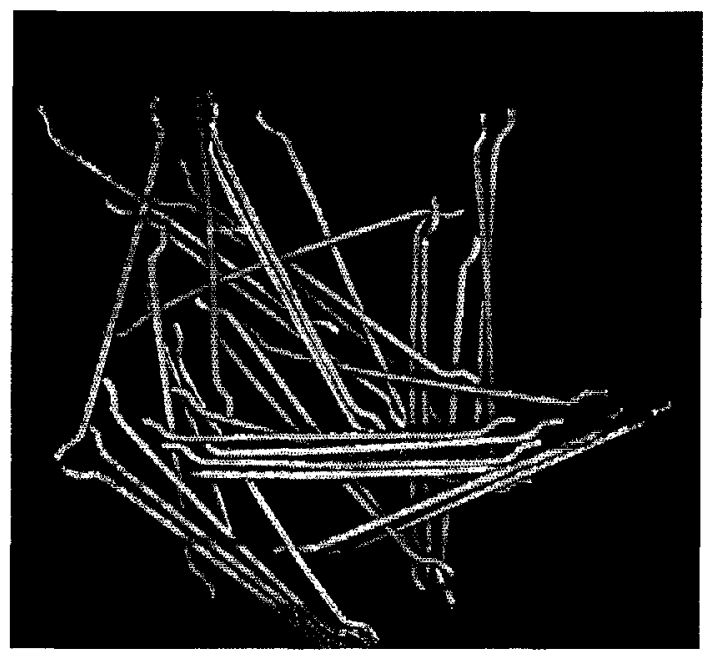

Figure 1. Dramix ${ }^{\circledR}$ RL $45 / 50$ hooked end steel fibres used in concrete.

Selected experiments were performed on concrete mixes that used recycled concrete as coarse aggregate. The recycled concrete was obtained from a 20 -year-old concrete residential patio that had been broken up with a jackhammer. The concrete had not been exposed to deicing salts. The original aggregate in the concrete patio was round siliceous stone with nominal maximum diameter of $38 \mathrm{~mm}$. The recycled concrete was sieved into three size fractions: 6.35 to $12.7 \mathrm{~mm}, 12.7$ to $19.0 \mathrm{~mm}$, and 19 to $25.4 \mathrm{~mm}$. Figure 2 compares the natural and recycled concrete aggregates. The RCA consisted of a combination of relatively smooth pieces of unfractured stone, angular pieces of either mortar adhering to stone or mortar itself, and angular pieces of fractured stone. The smallest size fraction tended to have a greater proportion of mortar and lower proportion of unfractured stone than the larger size fractions. The specific gravity and absorption of the RCA and natural aggregate were measured in accordance with ASTM C127 and the results are presented in Table 2.

Table 2. Specific Gravity and Absorption Data for Aggregates

\begin{tabular}{|l|c|c|c|c|}
\hline Aggregate Type & $\begin{array}{c}\text { Bulk Specific } \\
\text { Gravity (SSD) }\end{array}$ & $\begin{array}{c}\text { Bulk Specific } \\
\text { Gravity (dry) }\end{array}$ & $\begin{array}{c}\text { Apparent } \\
\text { Specific Gravity }\end{array}$ & $\begin{array}{c}\text { Absorption } \\
(\%)\end{array}$ \\
\hline $\begin{array}{l}6.35-12.7 \mathrm{~mm} \\
\text { natural }\end{array}$ & 2.67 & 2.65 & 2.69 & 0.6 \\
\hline $\begin{array}{l}6.35-12.7 \mathrm{~mm} \\
\text { RCS }\end{array}$ & 2.43 & 2.29 & 2.65 & 5.9 \\
\hline $\begin{array}{l}12.7-19.0 \mathrm{~mm} \\
\text { RCA }\end{array}$ & 2.42 & 2.31 & 2.59 & 4.7 \\
\hline $\begin{array}{l}19.0-25.4 \mathrm{~mm} \\
\text { RCA }\end{array}$ & 2.46 & 2.36 & 2.61 & 4.1 \\
\hline
\end{tabular}




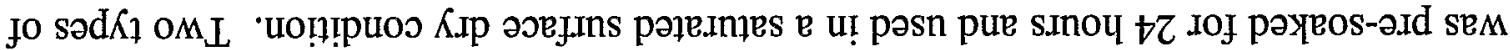

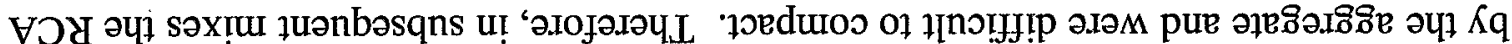

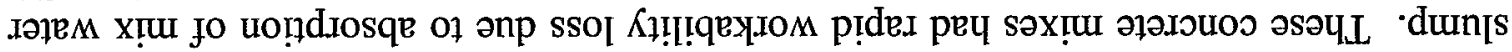

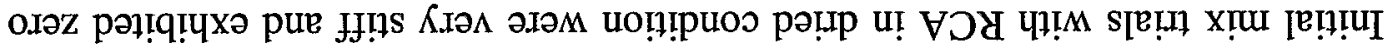

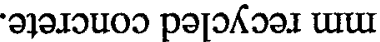

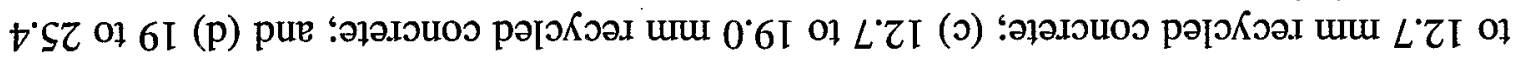

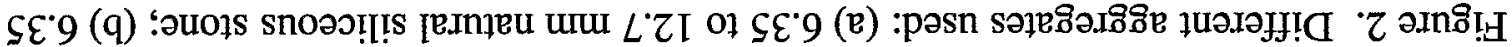

(p)

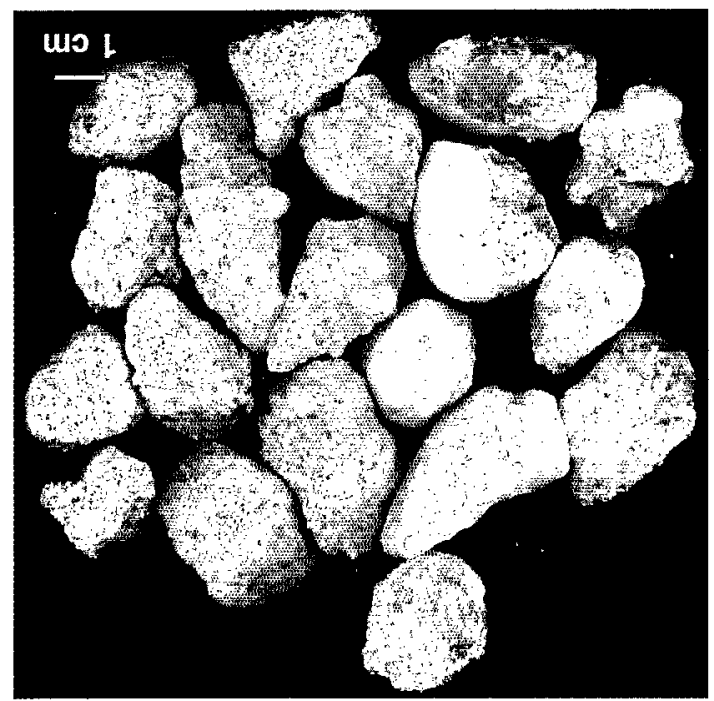

(q)

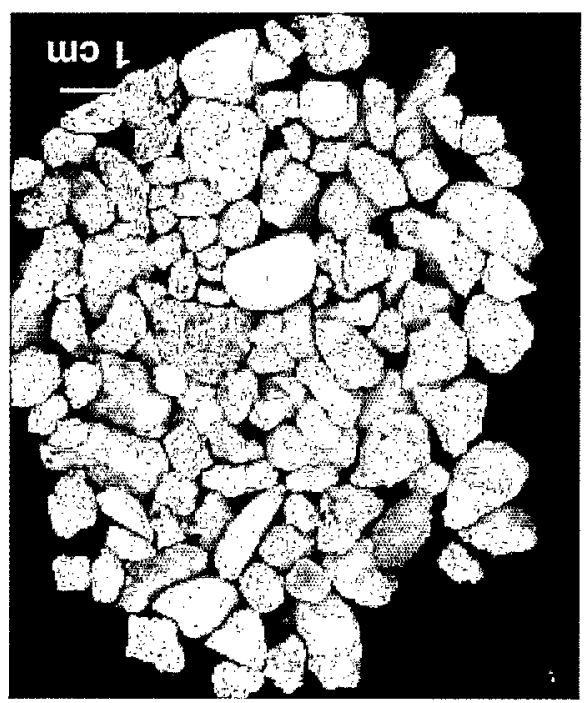

(ว)

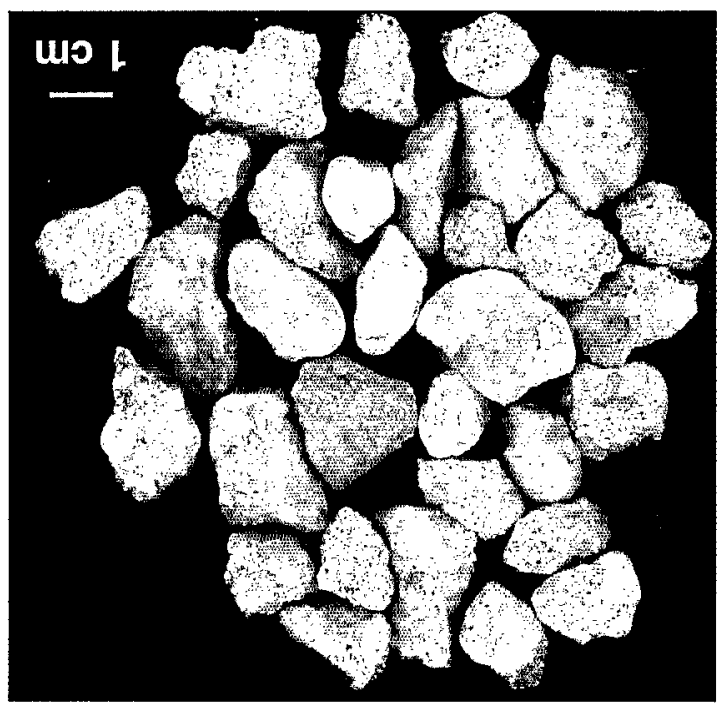

(e)

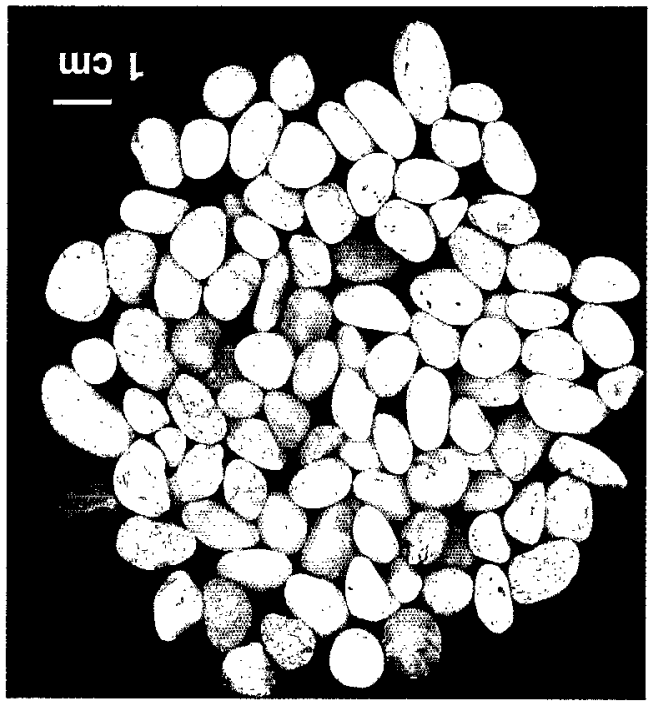


RCA mixes were investigated. The first contained $100 \%$ Portland cement and the second contained 50\% cement and 50\% blast furnace slag. The complete proportions for the mixes containing recycled concrete as aggregate are given in Table 3 . The water content refers to the added water and does not include that present in the aggregate. Mixes containing 6.35-12.7 mm RCA are designated by the suffix "RCS" and mixes with 12.7$19 \mathrm{~mm}$ and 19-25.4 mm RCA are designated by the suffix "RCA".

Table 3. Mix Proportions of Concrete with Recycled Concrete Aggregate

\begin{tabular}{|l|c|c|c|c|}
\hline & 100 OPC-RCS & 50 BFS-RCS & 100 OPC-RCA & 50 BFS-RCA \\
\hline Cement $\left(\mathrm{kg} / \mathrm{m}^{3}\right)$ & 370.4 & 184.5 & 394.8 & 196.1 \\
\hline BFS $\left(\mathrm{kg} / \mathrm{m}^{3}\right)$ & 0 & 184.5 & 0 & 196.1 \\
\hline Water $\left(\mathrm{kg} / \mathrm{m}^{3}\right)$ & 148.2 & 147.6 & 157.9 & 156.7 \\
\hline Sand $\left(\mathrm{kg} / \mathrm{m}^{3}\right)$ & 700.1 & 697.6 & 748.0 & 743.4 \\
\hline $\begin{array}{l}6.35-12.7 \mathrm{~mm} \\
\text { Aggregate }\left(\mathrm{kg} / \mathrm{m}^{3}\right)\end{array}$ & 1060.3 & 1056.6 & 0 & 0 \\
\hline $\begin{array}{l}12.7-19.0 \mathrm{~mm} \\
\text { Aggregate }\left(\mathrm{kg} / \mathrm{m}^{3}\right)\end{array}$ & 0 & 0 & 334.8 & 332.6 \\
\hline $\begin{array}{l}19.0-25.4 \mathrm{~mm} \\
\text { Aggregate }\left(\mathrm{kg} / \mathrm{m}^{3}\right)\end{array}$ & 0 & 0 & 680.6 & 677.0 \\
\hline $\begin{array}{l}\text { Superplasticizer } \\
\left(1 / \mathrm{m}^{3}\right)\end{array}$ & 3.70 & 3.69 & 3.95 & 3.92 \\
\hline Yield $\left(\mathrm{kg} / \mathrm{m}^{3}\right)$ & 2279 & 2271 & 2316 & 2302 \\
\hline Slump $(\mathrm{mm})$ & 65 & 70 & 85 & 85 \\
\hline
\end{tabular}

\subsection{Mixing Procedure}

The concrete was mixed in a $1.5 \mathrm{ft}^{3}$ Day pan mixer. The coarse and fine aggregates were first dry blended for 1 minute. Cement and any fly ash or slag were then added and dry blended for a further minute. Two thirds of the water-superplasticizer mix was added and mixing continued for another minute. The remaining water and superplasticizer were added and the total mixing time was five minutes.

\subsection{Compressive Strength}

The development of compressive strength in the concrete mixes containing natural aggregate was investigated. Concrete specimens were cast as cylinders, $102 \mathrm{~mm}$ diameter and $204 \mathrm{~mm}$ high, for compressive strength tests. The specimens were demoulded after 24 hours and wet cured for periods of 7, 28 and 84 days. After curing, the specimens were capped and tested in accordance with ASTM C 39 using a Forney compression tester. Six specimens per mix were tested. Concrete containing RCA was tested for 28- and 84-day compressive strength following the same curing and testing procedure. 


\subsection{Splitting Tensile Strength}

Cylindrical specimens, $152 \mathrm{~mm}$ in diameter and $305 \mathrm{~mm}$ high, were used in a series of splitting tensile strength tests following ASTM C 496-90. The materials tested included plain and fibre reinforced mixes containing either natural or recycled concrete aggregate. All cylinders were cured in water for 28 days and six specimens per mix were tested.

\subsection{Coefficient of Permeability (Hydraulic Conductivity)}

The water permeability (hydraulic conductivity) of the concrete under saturated conditions was measured in a flexible wall triaxial cell permeameter on cylindrical specimens $102 \mathrm{~mm}$ diameter and $90 \mathrm{~mm}$ long. The permeant was de-aired tap water at room temperature. The applied pressure gradient was $207 \mathrm{kPa}$ (30 psi) over the length of the specimen. The confining pressure applied to seal a latex membrane to the side surface of the concrete specimen was $414 \mathrm{kPa}(60 \mathrm{psi})$. The experimental set-up followed that given in ASTM D 5084-90. Measurements were taken after a wet curing period of 84 days.

\subsection{Elastic Modulus}

The dynamic elastic modulus was measured on three beams per mix in accordance with ASTM C 215. The beams were $76 \mathrm{~mm}$ by $102 \mathrm{~mm}$ by $406 \mathrm{~mm}$ and were wet cured for 28 days. Since the dynamic elastic modulus is sensitive to microcracking, this property was also used to monitor the performance of beams exposed to sulphate solutions.

\subsection{Thermal Conductivity}

Thermal conductivity of the concrete was measured on beams $76 \mathrm{~mm}$ by $102 \mathrm{~mm}$ by $406 \mathrm{~mm}$ using a Kyoto Electronics QTM-500 Thermal Conductivity Meter. This meter uses the hot wire method to determine thermal conductivity. The specimens were heated from an initial temperature of $70^{\circ} \mathrm{F}$ to $140^{\circ} \mathrm{F}$ over one minute during the test. All tests were performed on concrete in a wet condition.

\subsection{Exposure to Seawater}

The durability of concrete reinforced with $1 \%$ volume fraction Dramix ${ }^{\circledR}$ fibres exposed to artificial seawater was investigated. The composition of the seawater is given in Table 2. Cylinders $152 \mathrm{~mm}$ diameter and $305 \mathrm{~mm}$ high were cast and wet cured for 28 days. Six specimens per mix were cast. After curing the cylinders were immersed in a tank containing the seawater. Half the volume of seawater was pumped out twice a week to expose the top half of the cylinders to air while the bottom half remained immersed. Thus, the top half of the cylinders was subjected to wetting and drying cycles while the bottom half remained continuously submerged. The seawater was replaced on a monthly basis. The test duration was one year and the total number of cycles was 104 . The 
experimental procedure simulated tidal fluctuations in the top half and thereby enabled study of fibre corrosion in a tidal zone. Corrosion of the fibres in submerged concrete where oxygen access is restricted was studied in the bottom half. At the completion of the exposure period the cylinders per mix were subjected to splitting tensile strength tests. The condition of the fibres in the fractured specimens was examined visually.

Table 2. Composition of Artificial Seawater

\begin{tabular}{|c|c|}
\hline Component & Concentration (g/l) \\
\hline $\mathrm{NaCl}$ & 24.72 \\
\hline $\mathrm{KCl}$ & 0.67 \\
\hline $\mathrm{CaCl}_{2} \cdot 2 \mathrm{H}_{2} \mathrm{O}$ & 1.36 \\
\hline $\mathrm{MgCl}_{2} \cdot 6 \mathrm{H}_{2} \mathrm{O}$ & 4.66 \\
\hline $\mathrm{MgSO}_{4} \cdot 7 \mathrm{H}_{2} \mathrm{O}$ & 6.29 \\
\hline $\mathrm{NaHCO}_{3}$ & 0.18 \\
\hline
\end{tabular}

\subsection{Sulphate Resistance}

Degradation of concrete due to sulphates present in soil or groundwater is a potential concern for onshore wind turbine foundations. Therefore, the resistance of plain and fibre reinforced concrete to sulphate attack was determined by exposing beams to alternating wet-dry cycles in a $50 \mathrm{~g} / \mathrm{L}(0.35 \mathrm{M})$ solution of $\mathrm{Na}_{2} \mathrm{SO}_{4}$. The beams were 76 $\mathrm{mm}$ by $102 \mathrm{~mm}$ by $406 \mathrm{~mm}$ and were wet cured for 28 days prior to exposure to the $\mathrm{Na}_{2} \mathrm{SO}_{4}$. The sulphate solution was changed on a monthly basis and the total test duration was eight months. The dynamic elastic modulus of the beams was measured once per month in order to monitor degradation. All measurements were taken when the beams were in a wet condition.

\subsection{Polarization Studies on Steel Fibres}

The electrochemical characteristics of steel fibres embedded in the different concrete mixes were studied by determining polarization curves. Specimen preparation first consisted of covering individual fibres over three quarters of their length with heat shrink tubing. The partially covered ends of the fibres were then vertically embedded at specified lengths along the central axis of concrete beams $76 \mathrm{~mm}$ by $102 \mathrm{~mm}$ by $406 \mathrm{~mm}$. Dramix ${ }^{\circledR}$ fibres were embedded in each of the four mixes described in Table 1 . The beams were wet cured for 84 days and then cut to provide individual specimens with a single embedded fibre. The depth of cover to the fibres was 5 to $20 \mathrm{~mm}$. Figure 3 depicts the specimen details. The cut specimens were maintained in water for 28 days and then immersed in artificial seawater with the composition given in Table 2 for 126 days. Only specimens with $5 \mathrm{~mm}$ cover were undergoing corrosion by this time. Therefore, all results reported are for fibres with $5 \mathrm{~mm}$ cover.

Cyclic polarization curves were measured on individual embedded fibre specimens. Some of the specimens were tested after 28 days in water and others were tested after 126 days in artificial seawater. Specimens tested at 28 days were not re- 
tested to avoid any possible effects due to polarization. A computer controlled Gamry potentiostat was employed for the polarization studies. The reference electrode was saturated calomel and the counter electrode was carbon. Specimens were conditioned for one hour and a potential $200 \mathrm{mV}$ negative from the open circuit potential was applied. The potentiodynamic scan then proceeded in the positive direction at a rate of $1 \mathrm{mV} / \mathrm{s}$ until a current density of $5 \mathrm{~mA} / \mathrm{cm}^{2}$ was reached at which point the scan was reversed. A minimum of three curves was measured for each concrete mix. Tests were performed at $25^{\circ} \mathrm{C}$.

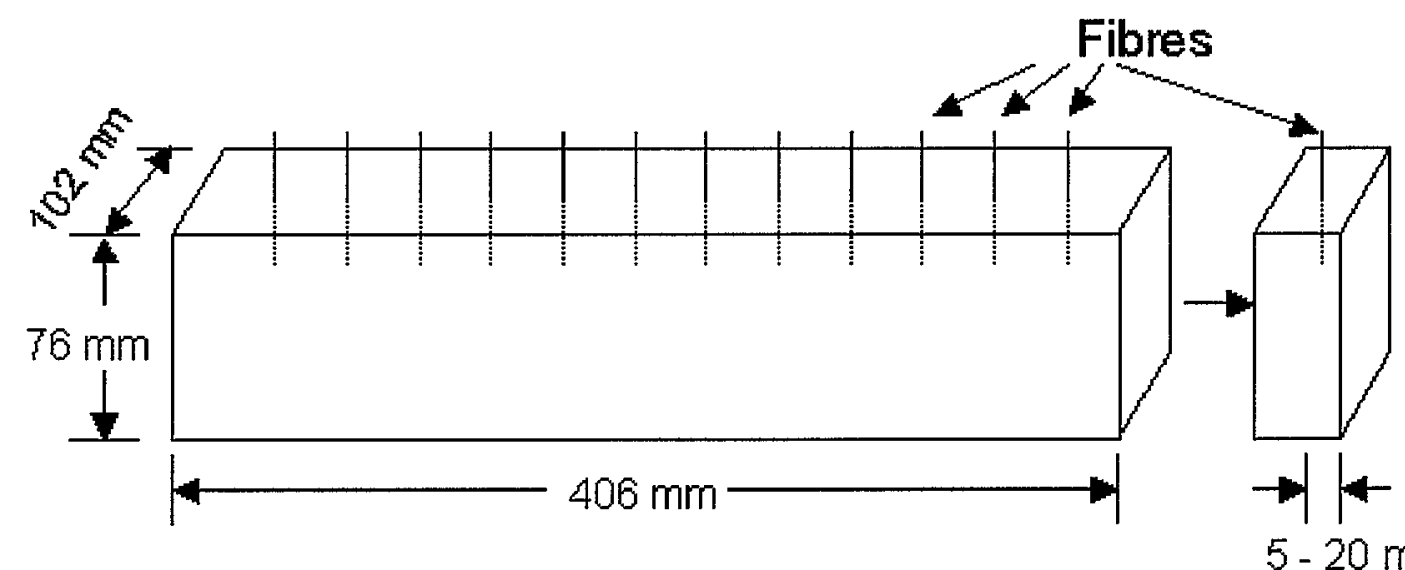

Cast Beam

Cut Specimen

Figure 3. Specimen Configuration for Electrochemical Potential Measurements on Embedded Fibres. 


\subsection{RESULTS}

\subsection{Macrostructure}

Figures 4 and 5 depict cross-sections of slag-modified concretes with natural and small sized recycled concrete aggregate, respectively.

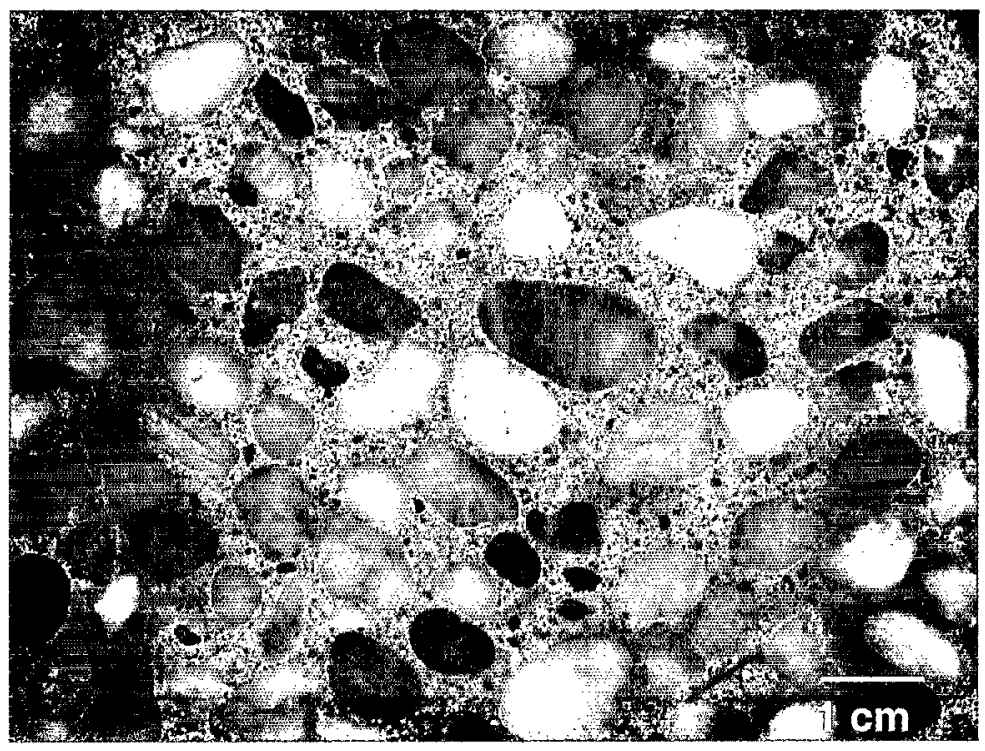

Figure 4. Cross-section of 50 BFS concrete with $6.35-12.7 \mathrm{~mm}$ natural stone aggregate. 


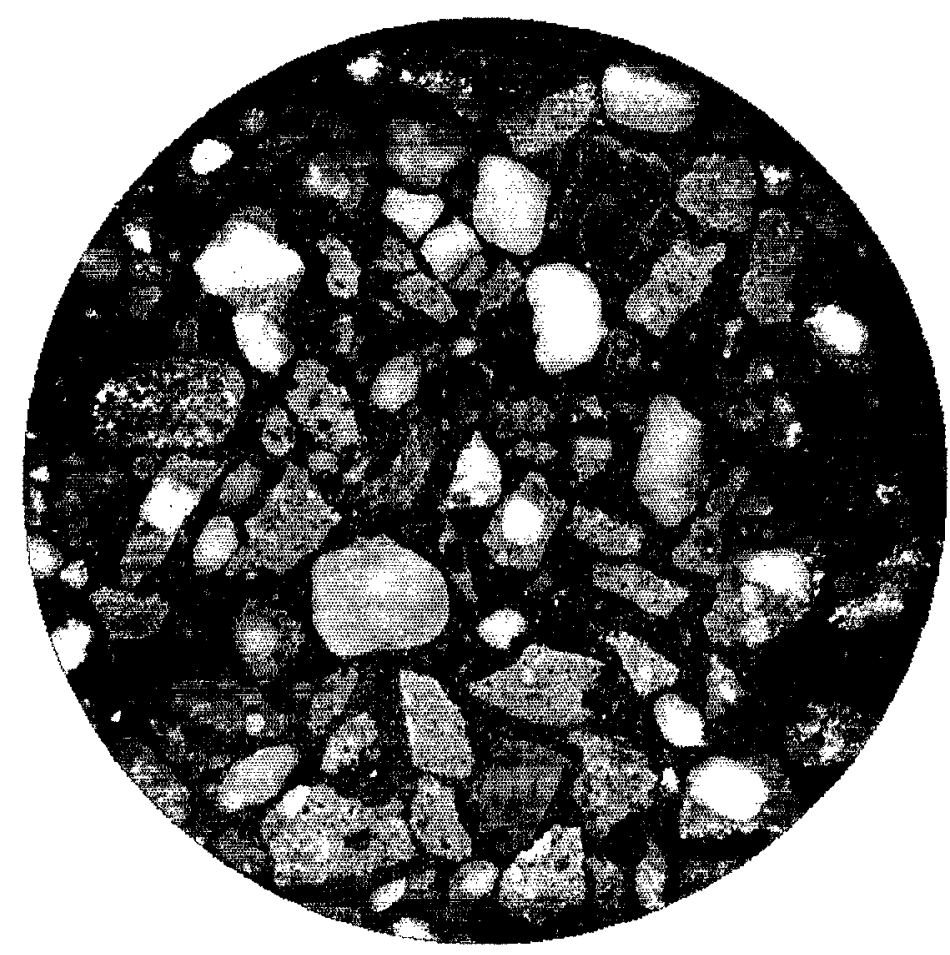

Figure 5. Cross-section of 50 BFS concrete with $6.35-12.7 \mathrm{~mm}$ recycled concrete aggregate.

\subsection{Compressive Strength}

The results of the compressive strength tests are presented in Table 3 and Figures 5, 6 and 7. The mean and standard deviation for six specimens per mix are given.

Table 3. Compressive Strength Data

\begin{tabular}{|c|c|c|c|}
\hline \multirow{2}{*}{ Mix } & \multicolumn{3}{|c|}{ Compressive Strength (MPa) } \\
\cline { 2 - 4 } & $\mathbf{7 ~ d a y s}$ & $\mathbf{2 8}$ days & $\mathbf{8 4}$ days \\
\hline 100 OPC & $36.5 \pm 1.1$ & $40.9 \pm 1.4$ & $47.0 \pm 0.8$ \\
\hline 50 FA & $16.4 \pm 0.4$ & $23.7 \pm 0.8$ & $36.7 \pm 1.3$ \\
\hline 50 BFS & $35.9 \pm 1.3$ & $45.7 \pm 2.0$ & $49.8 \pm 1.3$ \\
\hline 25 FA/25 BFS & $28.8 \pm 1.3$ & $36.6 \pm 2.0$ & $47.0 \pm 1.3$ \\
\hline 100 OPC-RCS & - & $44.0 \pm 0.8$ & - \\
\hline 50 BFS-RCS & - & $44.9 \pm 1.3$ & - \\
\hline 100 OPC-RCA & $32.4 \pm 0.6$ & $37.9 \pm 0.7$ & $42.6 \pm 1.4$ \\
\hline 50 BFS-RCA & $35.1 \pm 0.9$ & $43.7 \pm 1.0$ & $47.9 \pm 1.7$ \\
\hline
\end{tabular}




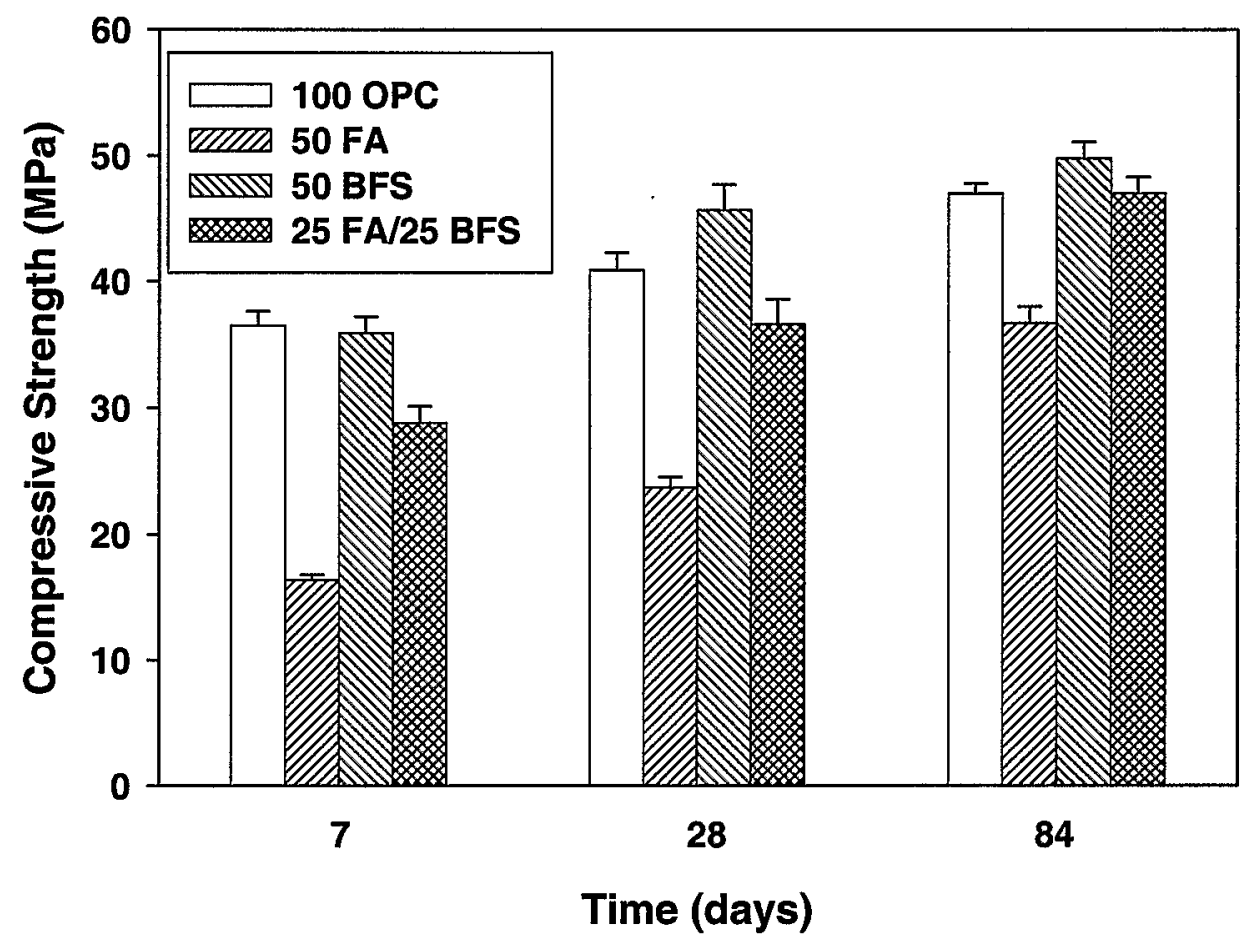

Figure 5. Compressive Strength of Concrete with Natural Aggregate versus Time.

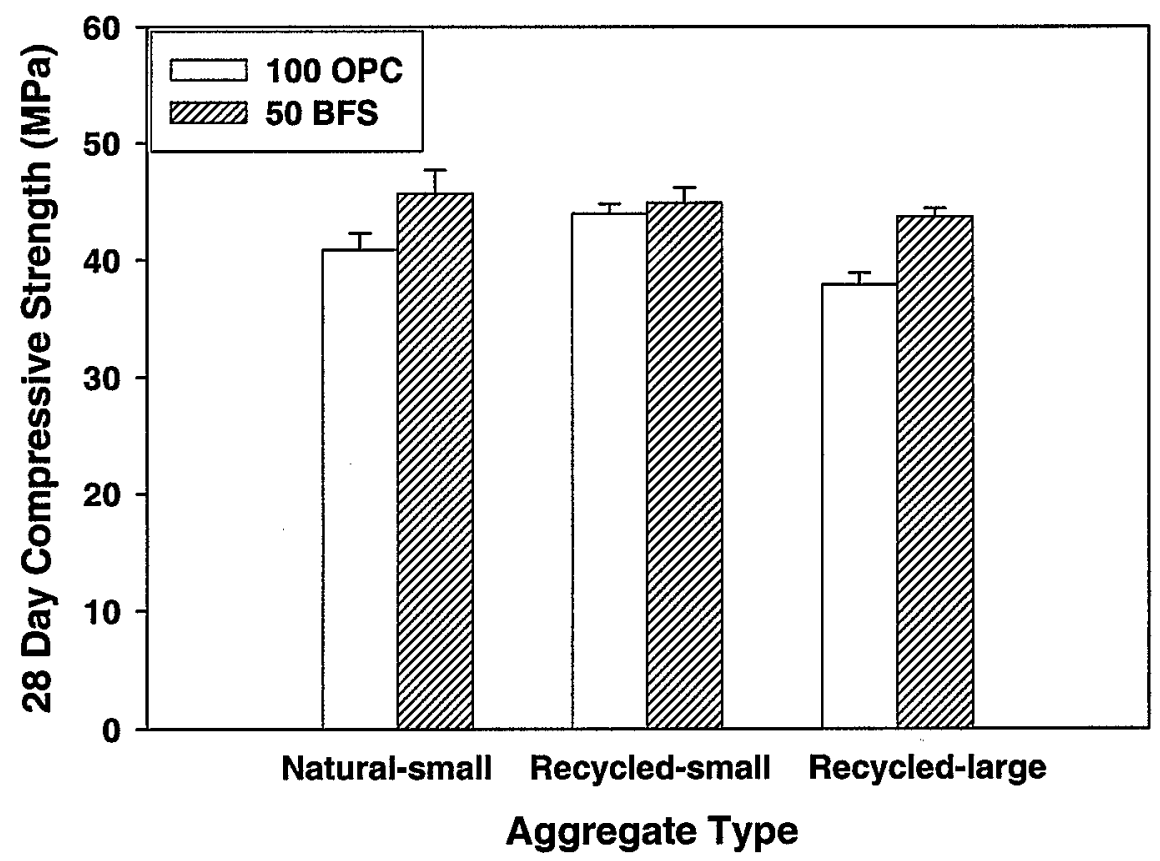

Figure 6. 28-Day Compressive Strength of Concrete for Different Aggregates. 


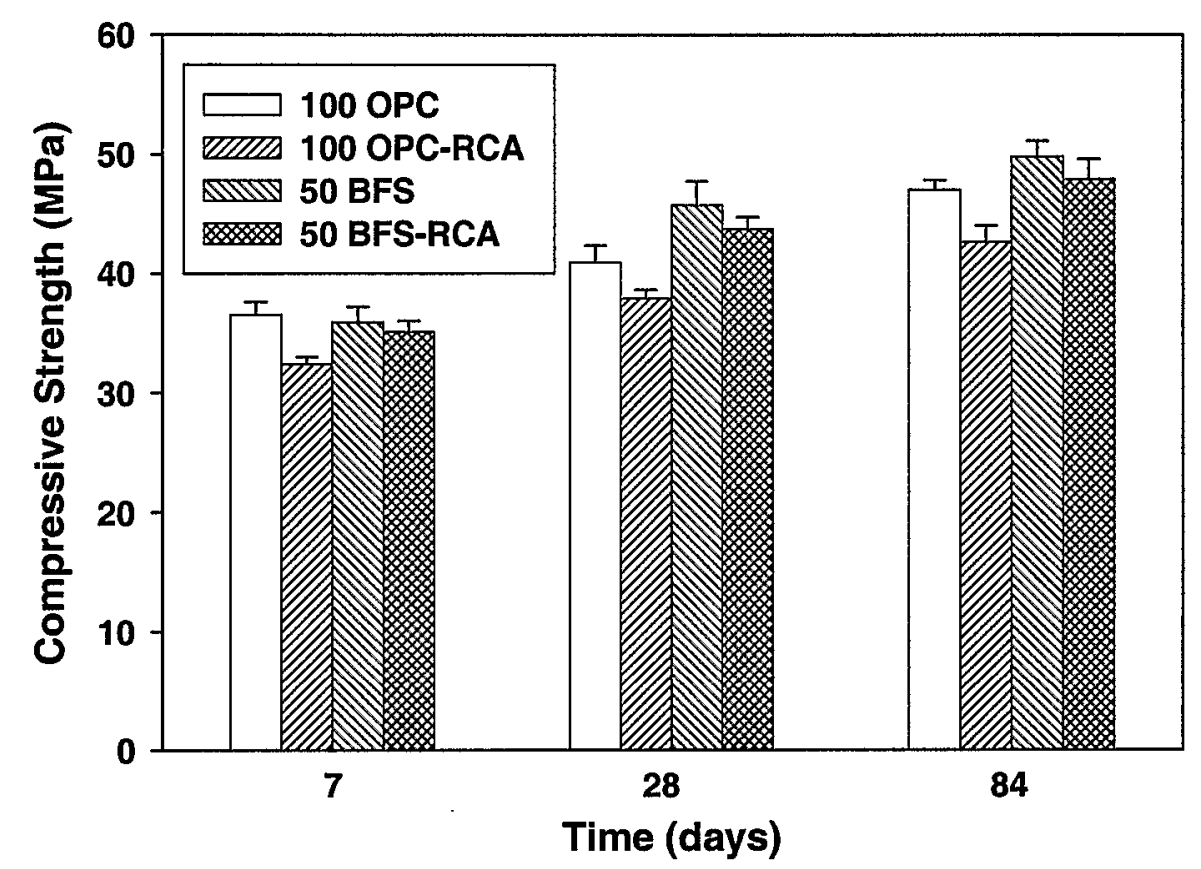

Figure 7. Compressive Strength of Concrete with Natural Aggregate and Large Recycled Aggregate (RCA) versus time.

\subsection{Splitting Tensile Strength}

The splitting tensile strengths of the plain and fibre reinforced (FR) concrete mixes are compared in Table 4 and Figure 7. The fracture surfaces of selected specimens are depicted in Figures 8 and 9.

Table 4. Splitting Tensile Strength

\begin{tabular}{|c|c|}
\hline Mix & Splitting Tensile Strength (MPa) \\
\hline 100 OPC & $2.31 \pm 0.18$ \\
\hline 100 OPC-FR & $4.08 \pm 0.29$ \\
\hline 50 FA & $1.69 \pm 0.12$ \\
\hline 50 FA-FR & $2.19 \pm 0.20$ \\
\hline 50 BFS & $2.83 \pm 0.25$ \\
\hline 50 BFS-FR & $4.53 \pm 0.35$ \\
\hline 25 FA/25 BFS & $2.41 \pm 0.17$ \\
\hline 25 FA/25 BFS-FR & $3.37 \pm 0.22$ \\
\hline 100 OPC-RCA & $2.29 \pm 0.08$ \\
\hline 100 OPC-RCA-FR & $3.87 \pm 0.35$ \\
\hline 50 BFS-RCA & $2.68 \pm 0.13$ \\
\hline 50 BFS-RCA-FR & $4.25 \pm 0.25$ \\
\hline
\end{tabular}




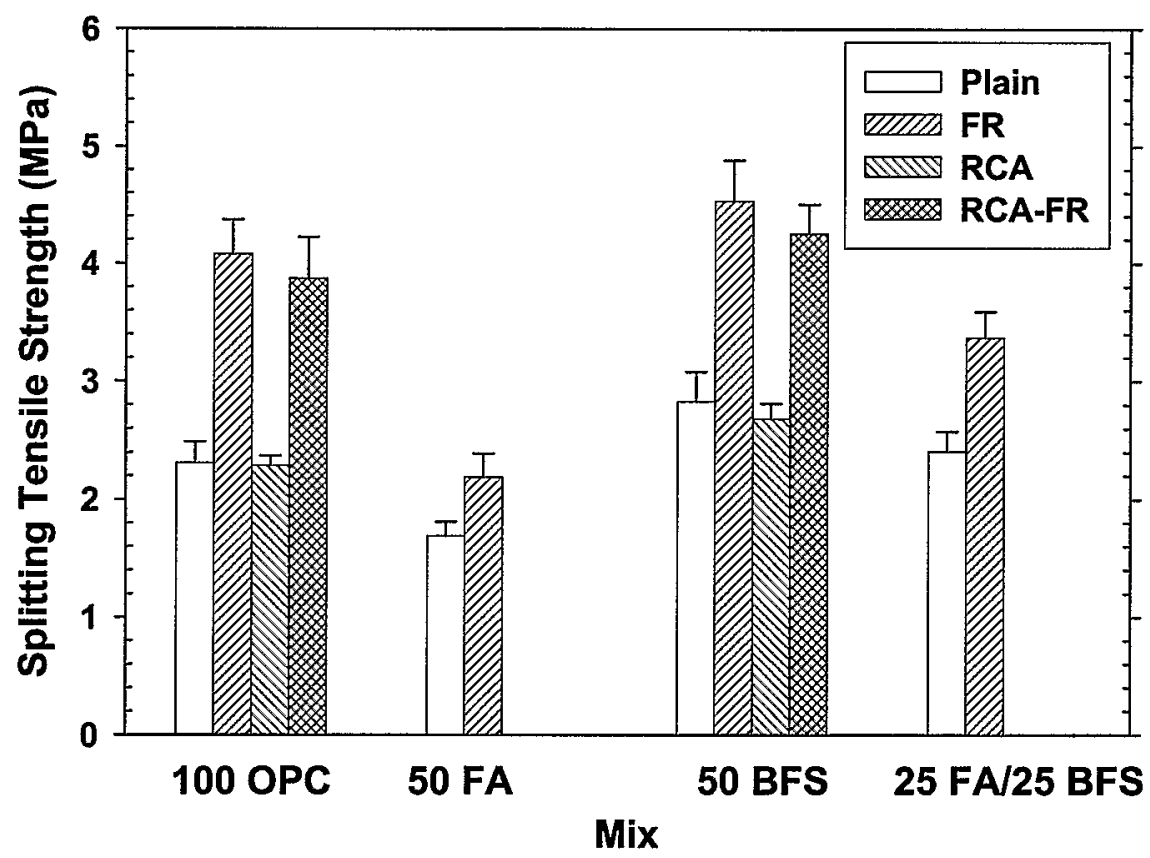

Figure 7. Splitting Tensile Strength of Plain, Fibre Reinforced (FR) and Recycled Aggregate (RCA) Concrete Mixes.

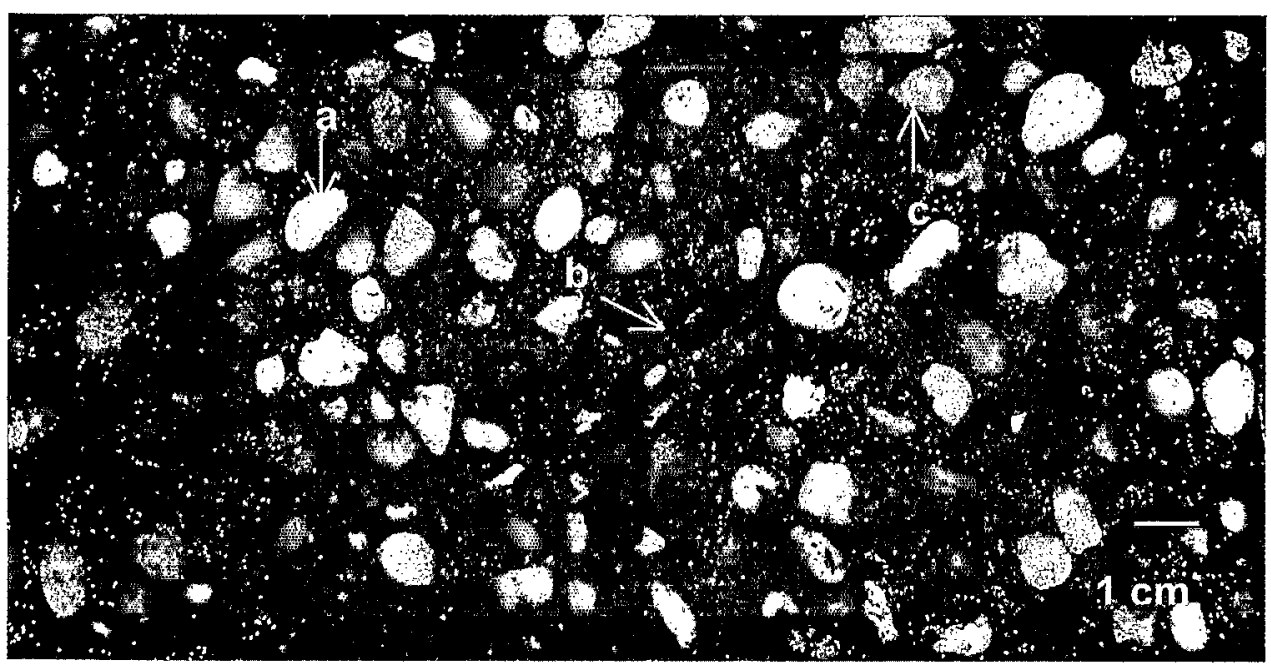

Figure 8. Fracture Surface of 50 BFS Concrete with Natural Aggregate Showing Examples of: (a) Unfractured Stone; (b) Stone Pullout; and (c) Fractured Stone. 


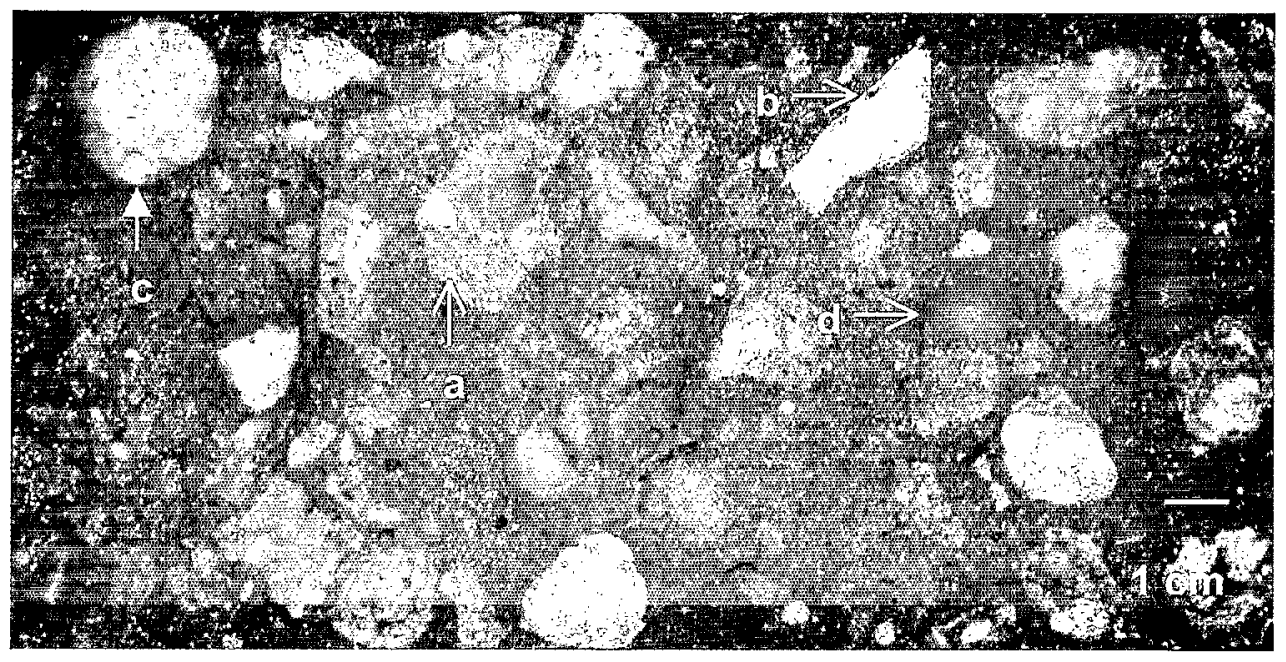

Figure 9. Fracture Surface of 50 BFS Concrete with Recycled Concrete Aggregate Showing Examples of: (a) Fractured Old Mortar; (b) Fractured Stone; (c) Unfractured Stone and (d) Stone Pullout.

\subsection{Coefficient of Permeability}

Table 5 summarizes the coefficient of permeability results after 84 days of curing. The mean and standard deviation for three specimens are given.

Table 5. Coefficient of Permeability Results

\begin{tabular}{|c|c|}
\hline Mix & Coefficient of Permeability (cm/s) \\
\hline 100 OPC & $1.1 \times 10^{-10} \pm 2 \times 10^{-11}$ \\
\hline $50 \mathrm{FA}$ & $2.6 \times 10^{-10} \pm 3 \times 10^{-11}$ \\
\hline 50 BFS & $1.2 \times 10^{-10} \pm 3 \times 10^{-11}$ \\
\hline $25 \mathrm{FA} / 25 \mathrm{BFS}$ & $1.0 \times 10^{-10} \pm 2 \times 10^{-11}$ \\
\hline 100 OPC-RCA & $1.7 \times 10^{-10} \pm 2 \times 10^{-11}$ \\
\hline $50 \mathrm{BFS}-\mathrm{RCA}$ & $1.7 \times 10^{-10} \pm 2 \times 10^{-11}$ \\
\hline
\end{tabular}

\subsection{Elastic Modulus}

The dynamic elastic modulus data for the different concrete mixes at 28 days are presented in Table 6. 
Table 6. Elastic Modulus Data

\begin{tabular}{|c|c|}
\hline Mix & Elastic Modulus (GPa) \\
\hline 100 OPC & $47.2 \pm 0.3$ \\
\hline $50 \mathrm{FA}$ & $37.7 \pm 0.2$ \\
\hline $50 \mathrm{BFS}$ & $47.4 \pm 0.6$ \\
\hline $25 \mathrm{FA} / 25 \mathrm{BFS}$ & $44.0 \pm 0.9$ \\
\hline 100 OPC-RCA & $40.1 \pm 0.3$ \\
\hline 50 BFS-RCA & $37.7 \pm 1.0$ \\
\hline
\end{tabular}

\subsection{Thermal Conductivity}

Table 7 gives the thermal conductivity data for the concrete mixes.

Table 7. Thermal Conductivity Data

\begin{tabular}{|c|c|}
\hline Mix & Thermal Conductivity (W/m.K) \\
\hline 100 OPC & $3.841 \pm 0.217$ \\
\hline 50 FA & $4.148 \pm 0.200$ \\
\hline 50 BFS & $4.548 \pm 0.052$ \\
\hline 25 FA/25 BFS & $3.947 \pm 0.189$ \\
\hline 100 OPC-RCA & $3.0941 \pm 0.084$ \\
\hline 50 BFS-RCA & $3.1836 \pm 0.152$ \\
\hline
\end{tabular}

\subsection{Exposure to Seawater}

Table 8 presents the results of the splitting tensile strength tests for the fibre reinforced cylinders exposed to seawater for one year. The results are compared with 28day values for equivalent mixes in Figure 10. The specimens exposed to seawater showed staining due to corrosion of fibres close to the outside surface. There was no obvious difference in degree of staining for the different mixes. Also, staining occurred in both the submerged and simulated tidal zone. Observations of the fractured specimens indicated that corrosion of fibres was limited to depths of $0.5 \mathrm{~mm}$ and that the corrosion was slight. Beyond this, the fibres did not exhibit any corrosion and remained bright. Corrosion of fibres close to the surface did not result in significant loss of cross-section. The corroded fibres in the submerged zone tended to be black and this was indicative of $\mathrm{Fe}_{3} \mathrm{O}_{4}$ corrosion products associated with low oxygen content.

Table 8. Splitting Tensile Strength of Specimens Exposed to Seawater.

\begin{tabular}{|c|c|}
\hline Mix & Splitting Tensile Strength (MPa) \\
\hline 100 OPC-FR & $4.43 \pm 0.31$ \\
\hline 50 FA-FR & $2.78 \pm 0.25$ \\
\hline 50 BFS-FR & $5.06 \pm 0.42$ \\
\hline 25 FA/25 BFS-FR & $4.12 \pm 0.35$ \\
\hline
\end{tabular}




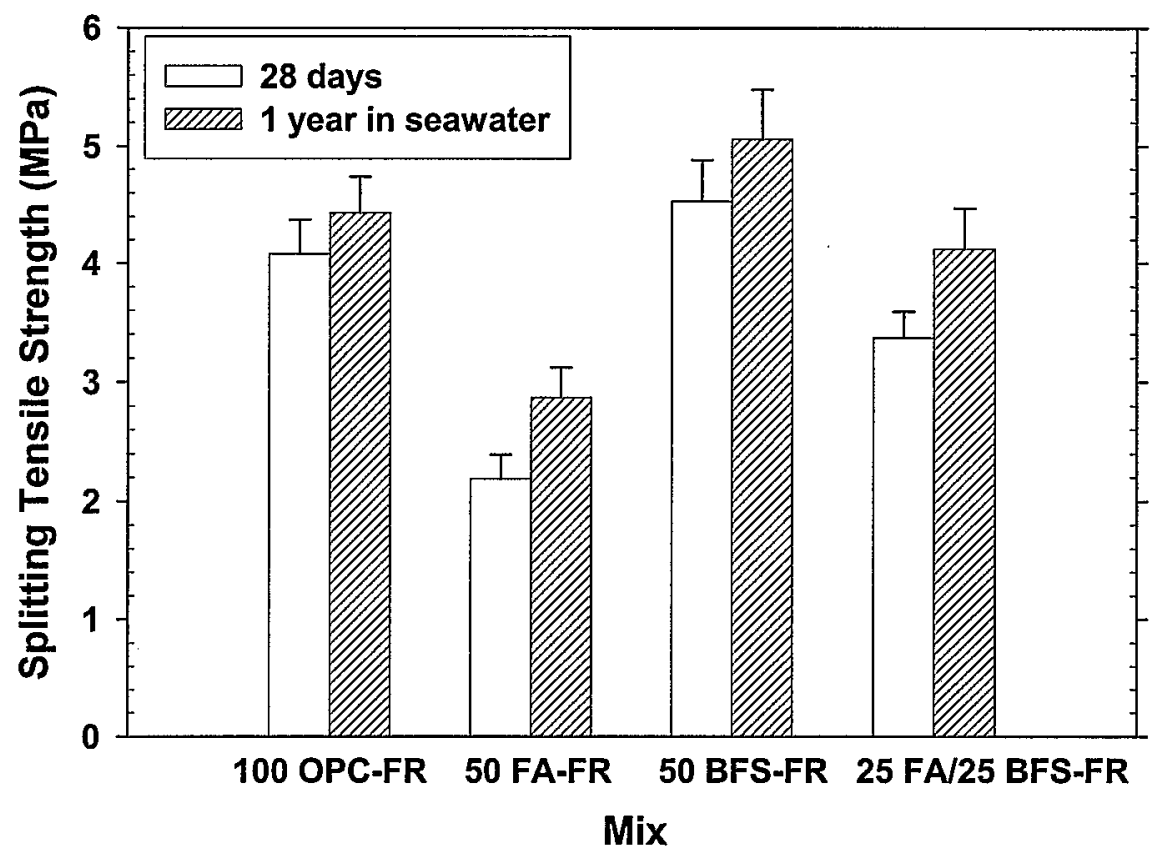

Figure 10. Splitting Tensile Strength of Fibre Reinforced Concrete Before and After Seawater Exposure.

\subsection{Sulphate Resistance}

Table 9 and Figure 11 shows the mean dynamic modulus versus time of the beams exposed to the sulphate solution. After six months of exposure there were no visible signs of deterioration on any of the beams. However, it is noted that a latency period exists for sulphate attack and longer-term exposure is necessary to obtain more realistic indications of durability for extended service life.

Table 9. Dynamic Elastic Modulus Results from Sulphate Exposure Tests

\begin{tabular}{|c|c|c|c|c|}
\hline \multirow{2}{*}{ Time (months) } & \multicolumn{4}{|c|}{ Dynamic Modulus (GPa) } \\
\cline { 2 - 5 } & $\mathbf{1 0 0}$ OPC & 50 FA & 50 BFS & 25FA/25BFS \\
\hline 0 & $47.2 \pm 0.3$ & $37.7 \pm 0.2$ & $47.4 \pm 0.6$ & $44.0 \pm 0.9$ \\
\hline 1 & $48.9 \pm 1.0$ & $44.9 \pm 0.7$ & $49.5 \pm 0.3$ & $46.7 \pm 0.4$ \\
\hline 2 & $50.4 \pm 0.5$ & $46.6 \pm 0.9$ & $50.3 \pm 1.0$ & $48.3 \pm 0.4$ \\
\hline 3 & $50.4 \pm 0.5$ & $46.8 \pm 0.7$ & $50.0 \pm 0.6$ & $49.1 \pm 0.9$ \\
\hline 4 & $49.9 \pm 0.2$ & $46.8 \pm 0.7$ & $50.0 \pm 0.6$ & $48.9 \pm 0.6$ \\
\hline 5 & $49.9 \pm 0.2$ & $47.3 \pm 0.2$ & $50.3 \pm 0.9$ & $48.9 \pm 0.6$ \\
\hline 6 & $50.1 \pm 0.3$ & $47.5 \pm 0.1$ & $50.3 \pm 0.5$ & $48.9 \pm 0.6$ \\
\hline
\end{tabular}




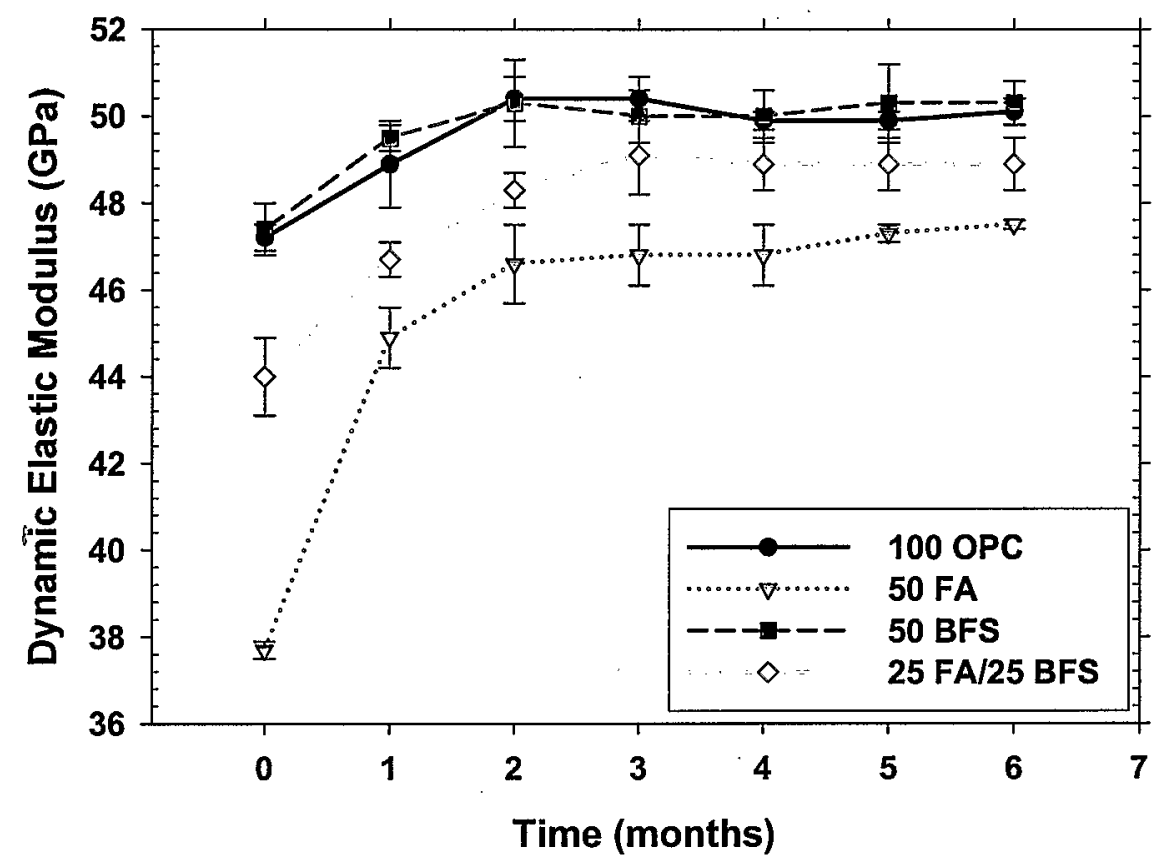

Figure 11. Dynamic Elastic Modulus versus Time for Beams Exposed to Sulphate Solution.

\subsection{Polarization Curves for Fibre Reinforced Concrete}

Figure 12 shows typical potential versus time curves for Dramix ${ }^{\circledR}$ fibres embedded in the different concrete mixes maintained in water. The potentials decreased to values in the range of -0.505 to $-0.554 \mathrm{~V}$ vs. SCE once corrosion was initiated. Figures 13 and 14 are typical polarization curves for the embedded fibres after 28 days in water and after 126 days in seawater, respectively. 


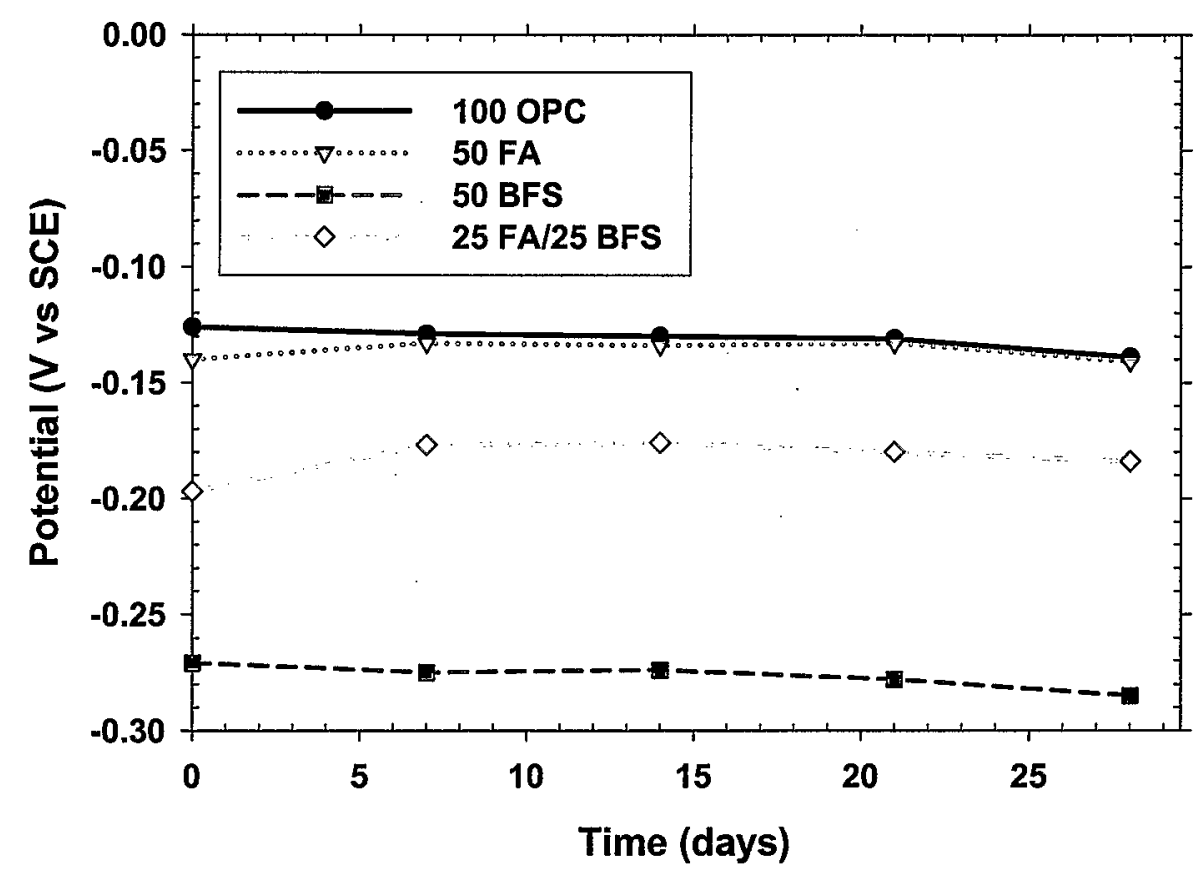

Figure 12. Typical potential versus time curves of steel fibres embedded in different concrete mixes and maintained in water.

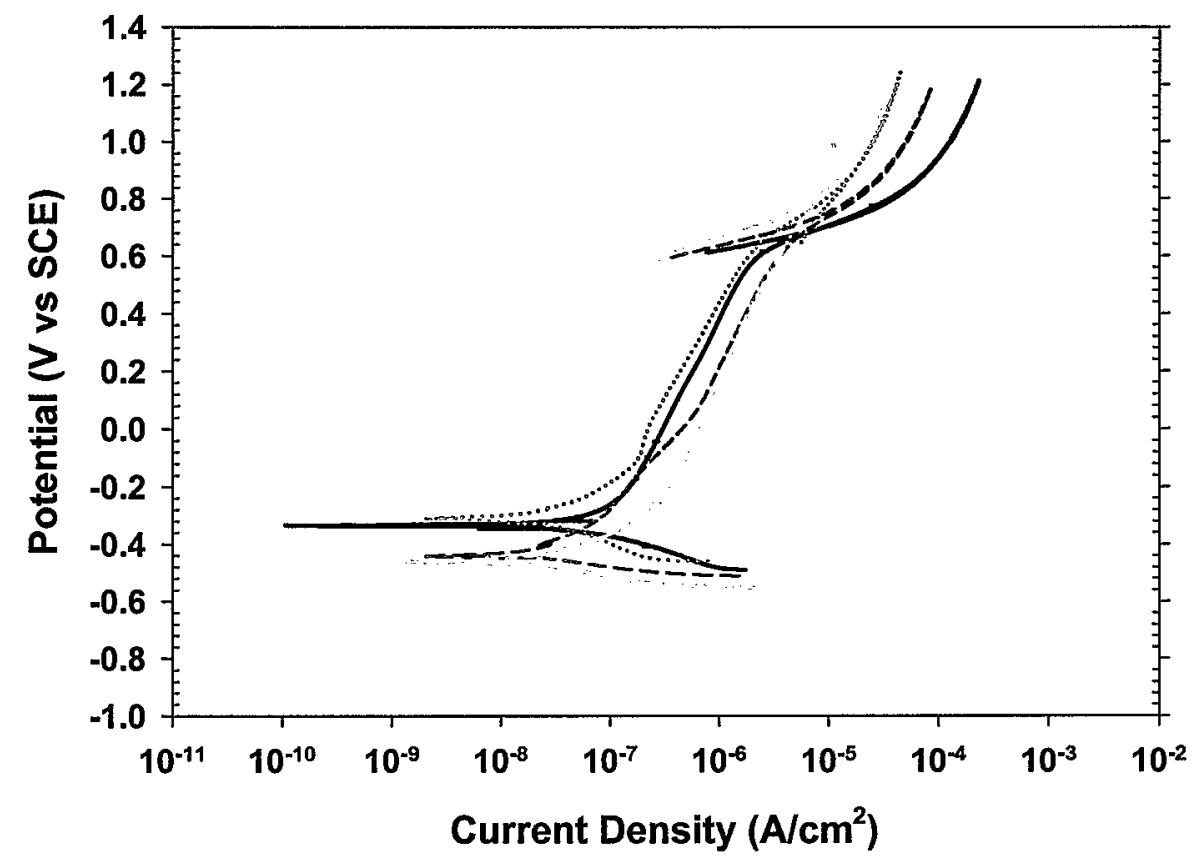

Figure 13. Polarization curves for fibres embedded in different concrete mixes after exposure in water. 


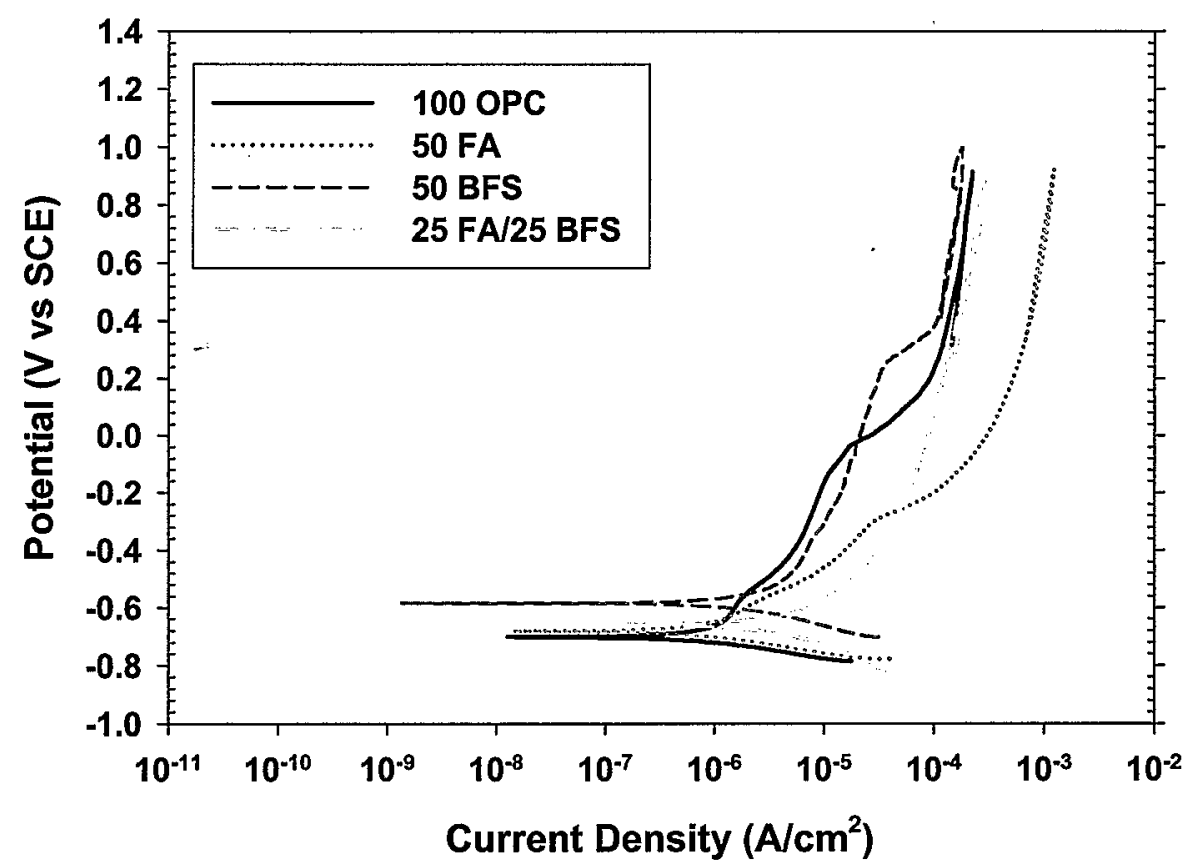

Figure 14. Polarization curves for fibres embedded in different concrete mixes after exposure in seawater. 


\subsection{DISCUSSION}

\subsection{Workability}

Other than the concrete containing dry RCA, all mixes exhibited good workability and were readily compacted. Fly ash gave the most significant improvement in workability. Addition of fibres was compatible with all the mixes, although workability was reduced somewhat.

\subsection{Compressive Strength}

The compressive strength results for concrete containing natural aggregate in Table 3 and Figure 3 show that partial replacement of cement with $50 \%$ fly ash results in decreased strength, particularly at 7 days. Although the strength of this mix does improve with curing, its strength at 84 days was less than $40 \mathrm{MPa}$ and it remained the weakest of all mixes tested. For this reason, fly ash was omitted from the mixes containing RCA. Inclusion of 50\% blast furnace slag in the natural aggregate mixes was beneficial, giving the highest strength at 28 and 84 days. Blending $25 \%$ fly ash and $25 \%$ slag resulted in improved strengths at all ages compared with the $50 \%$ fly ash mix, particularly at 84 days. The results demonstrate that $40 \mathrm{MPa}$ compressive strength can be readily achieved at 28 days with a sustainable mix design containing $50 \%$ slag as partial replacement of cement and that long term strength under wet curing conditions can also be achieved with mixes containing $25 \%$ fly ash $/ 25 \%$ slag.

Concrete containing 6.35-12.7 mm RCA had 28-day mean compressive strengths of 44.0 and $44.9 \mathrm{MPa}$ for the $100 \mathrm{OPC}-\mathrm{RCS}$ and $50 \mathrm{BFS}-\mathrm{RCS}$ mixes, respectively. This compares with values of 40.9 and $45.7 \mathrm{MPa}$ for the natural aggregate $100 \mathrm{OPC}$ and 50 BFS mixes, respectively. Thus, the use of the small sized recycled aggregate was not detrimental to 28-day compressive strength, and actually improved the mean value for the $100 \mathrm{OPC}$ mix. The increased strength is possibly due to the angularity and rough surface texture of the recycled aggregate as compared to the round, smooth natural aggregate and the resultant enhanced bonding to cement paste.

In general, lower compressive strengths were obtained for the concrete incorporating the blend of larger sized RCA than the natural aggregate or small RCA, particularly for the mixes without slag (100 OPC). Figure 4 compares the 28-day strengths for concretes with different aggregate types and also shows the impact of partial replacement of cement with $50 \%$ slag. Addition of slag improved the 28-day strengths for the mixes with the natural aggregate and the large RCA. Interestingly, the impact of slag on strength was negligible for the small RCA. The strength development of the mixes with large RCA is indicated in Figure 5 and also compared with that for concrete with natural aggregate. The results showed that slag was beneficial for the large RCA mixes at all ages. In addition, the difference in mean strength between natural and large RCA concretes was lower for mixes containing slag. 
Recent research on RCA concrete has generally shown that compressive strength is reduced by RCA as compared to natural aggregate (e.g., Gómez-Soberón, 2002; Park, 1999; 2001; Ahmad et al., 1996). However, Sagoe-Crentsil et al. (2001) found equivalent strength and Tavakoli and Soroushian (1996) achieved higher strengths with one source of RCA. The effect of RCA on compressive strength appears to be highly dependent on original concrete quality and mix proportions, in addition to water/cement ratio, and workability. Shayan and Xu (2003) found that high 28-day compressive strength of RCA mixes could be produced when silica fume was incorporated in the mix or if the RCA was pretreated with silica fume slurry. For the type of aggregates and mix proportions studied in the present research it was evident that strength decrease associated with RCA could be mitigated with slag. Therefore, the use of slag or silica fume in combination with $\mathrm{RCA}$ is recommended.

\subsection{Splitting Tensile Strength}

As shown in Table 4 and Figure 7, the splitting tensile strength of the plain natural aggregate mixes was increased by incorporation of slag and decreased by incorporation of fly ash. The FA/BFS blend had a mean strength in between that of the mixes with either slag or fly ash. Addition of $1 \%$ volume fraction of steel fibres resulted in improved tensile strength for all mixes, with the greatest impact being observed for the concretes containing slag or without any supplementary cementing materials. The mean splitting tensile strength increased by 77 and $60 \%$ on addition of fibres for the $100 \mathrm{OPC}$ and 50 BFS mixes, respectively. Concrete containing fly ash did not respond to such a degree with fibre reinforcement and the increases in mean tensile strength were 29 and $40 \%$ for the $50 \mathrm{FA}$ and $25 \mathrm{FA} / 25 \mathrm{BFS}$ mixes, respectively.

The tensile strengths of the plain and fibre reinforced RCA mixes were generally comparable to those of the equivalent natural aggregate formulations. Fibre reinforcement resulted in mean tensile strength increases of 69 and $59 \%$ for the 100 OPCRCA and 50 BFS-RCA mixes, respectively. Replacement of 50\% cement with slag led to improved tensile strength for the RCA formulations. This was consistent with the achievement of enhanced compressive strength for slag-modified RCA mixes. Increased compressive and splitting tensile strengths of RCA concrete using slag cement $(65 \%$ Portland cement/ $35 \%$ blast furnace slag) have also been measured by Sagoe-Crentsil et al. (2001).

Examination of the fracture surfaces indicated that, in addition to the matrix itself, fracture was primarily at the stone/matrix interface and through stone for the natural aggregate mixes. The RCA mixes primarily exhibited fracture through old mortar particles and through stone. Fracture at relatively bare stone/matrix interfaces occurred to a lesser degree. The interfaces between old mortar and new matrix generally remained intact and this observation implies good interfacial bonding.

Based on the results obtained, it is recommended that steel fibres in conjunction with slag be used if increased tensile strength of wind turbine foundation concrete is required. This recommendation is applicable to both natural aggregate and RCA mixes. 


\subsection{Coefficient of Permeability}

The results in Table 5 show that the coefficients of permeability of the $100 \mathrm{OPC}, 50$ $\mathrm{BFS}$ and $25 \mathrm{FA} / 25$. BFS after 84 days of wet curing were very similar. Partial replacement of cement with $50 \%$ fly ash (50 FA) led to a significant increase in permeability. Use of RCA also resulted in increased permeability, although the impact was not as great as that of $50 \%$ fly ash. The higher permeability is probably associated with the mortar in the RCA and the higher actual water/cement ratio due to pre-soaking of the recycled aggregate. The slag-modified concretes with either natural aggregate or RCA had equivalent coefficients of permeability to those without slag.

In all cases the coefficient of permeability remained of the order of $10^{-10} \mathrm{~cm} / \mathrm{s}$ and this is acceptable for durable concrete. Therefore, any of the mixes are suitable for wind turbine foundations provided other mechanical properties and predictive measures of durability are also acceptable. Preference should be given to the lower permeability mixes.

\subsection{Elastic Modulus}

The 28-day dynamic elastic moduli of the $100 \mathrm{OPC}$ and $50 \mathrm{BFS}$ mixes were essentially equivalent as shown in Table 6 . Addition of fly ash to the concrete caused the modulus to decrease, particularly for the 50 FA mix. However, additional curing may result in an increase in modulus with time all mixes, particularly that containing fly ash. Elastic modulus was also decreased for concrete containing RCA. The latter decrease is consistent with findings by Gómez-Soberón (2002). The lower modulus for the RCA mix may have an impact on the structural response and future research will examine this aspect.

\subsection{Thermal Conductivity}

The thermal conductivity data for the natural aggregate concretes in Table 7 indicate that slag tends to increase conductivity for the mix proportions studied. Lower thermal conductivities were obtained for the RCA mixes and this is a reflection of the presence of a high proportion of mortar as aggregate. The influence of thermal conductivity of the different concretes on the response to thermal loads will be investigated in the future.

\subsection{Durability in Seawater}

The fibre reinforced concrete exposed to seawater for one year showed minor fibre corrosion and was confined to fibres close to the concrete surface. The initial findings of good durability for the fibre reinforced concrete are consistent with previous reports (Hoff, 1987; Mangat and Gurusamy, 1988; Raupach and Dauberschmidt, 2002). It has been proposed by Mangat and Molloy (2000) that the superior corrosion resistance of fibres in concrete as compared with rebar is due to surface homogeneity. 
The splitting tensile strength of fibre reinforced concrete was not detrimentally affected by exposure to seawater for one year as shown in Figure 10. Strength did increase somewhat and this is due to prolonged curing in the seawater. Studies by Kosa and Naaman (1990) showed that reduction of direct tensile strength of steel fibre reinforced mortar could occur if corrosion is significant and results in reduction of fibre diameter.

\subsection{Sulphate Resistance}

The beams exposed to a $0.35 \mathrm{Na}_{2} \mathrm{SO}_{4}$ solution did not exhibit visible deterioration in the test period of six months. The dynamic modulus results in Table 9 and Figure 11 showed that the modulus actually increased over the first two months of exposure, especially for the $50 \mathrm{FA}$ mix, and then stabilized. This increased was probably due to ongoing curing. A longer test duration would be required to make comparisons of the sulphate resistance of the different concrete mixes. Sulphate attack would be expected to be most severe for the 100 OPC mix and continued exposure would lead to degradation and decrease in dynamic modulus.

\subsection{Polarization Curves}

The potential versus time curves for fibre reinforced specimens maintained in water (Figure 12) show that the potentials of fibres embedded in the 100 OPC and 50 FA mixes tended to be similar whereas those for the $50 \mathrm{BFS}$ and $25 \mathrm{FA} / 25 \mathrm{BFS}$ mixes were more negative, particularly for $50 \mathrm{BFS}$. This is associated with the reducing characteristics of blast furnace slag.

Figure 13 shows that the cyclic polarization curves for the fibres in the different concretes exposed to water have similar features. In general, fibres embedded in the 100 OPC mix had lower pitting potentials than the other concretes. Addition of slag tended to make the corrosion and pitting potentials more positive. The corrosion current densities tended to be slightly higher for both mixes containing slag as compared with the 100 $\mathrm{OPC}$ and $50 \mathrm{FA}$ mixes. After seawater exposure and initiation of corrosion the polarization curves in Figure 14 exhibit more active behaviour. The curves tended to be more variable for different specimens. For all mixes the corrosion current density was of the order of $10^{-6} \mathrm{~A} / \mathrm{cm}^{2}$. 


\subsection{CONCLUSIONS}

Basic properties of sustainable concrete mixes have been investigated in this preliminary study and it is concluded that sustainability and economic concepts are compatible with mix design for large wind turbine foundations. The initial results indicate that mixes containing 50\% replacement of cement with blast furnace slag give the best results in terms of mechanical properties and durability. Recycled concrete aggregate can also be used without significant detriment to strength, particularly if the concrete also contains slag. Coefficient of permeability was increased by a small degree by fly ash or recycled concrete aggregate, although the values remained acceptable for durable concrete. Elastic modulus is decreased when either fly ash or recycled concrete aggregate are incorporated in concrete and the impact of this on the structural response of foundations needs to be investigated. Steel fibre reinforcement can enhance the tensile properties of sustainable concrete and initial durability studies show that corrosion of the fibres is minimal after one year of exposure to artificial seawater.

\subsection{RECOMMENDATIONS}

It is recommended that more detailed studies of mix design and properties of concrete for wind turbine foundations are conducted with emphasis on slag-modified mixes with natural and recycled concrete aggregate. The proportion of slag that can be incorporated in the concrete needs to be optimized, as does the grading of recycled aggregate. The potential for using silica fume in conjunction with slag is worth exploring as this may further enhance strength and durability. Longer-term durability studies are necessary to predict service life and use the proposed mixes with confidence. Other pertinent properties of concrete that require investigation include damping characteristics, pullout strength, fatigue strength and risk of thermal cracking. The potential for increased drying shrinkage of mixes containing recycled concrete aggregate needs to be considered.

The properties of sustainable concrete mixes need to be integrated with studies on the structural behaviour of wind turbine foundations in order to determine the optimal mix design and to examine means of reducing conservatism and cost of foundations. The concept of using fibre reinforcement to reduce the amount of bar reinforcement and improve properties such as tensile and fatigue strength needs to be included in foundation design and associated engineering analysis.

\subsection{REFERENCES}

S.H. Ahmad, D. Fisher and K. Sackett, Mechanical Properties of Concretes with North Carolina Recycled Aggregates, in Integrated Design and Environmental Issues in Concrete Technology, K. Sakai (Ed.), E \& FN Spon, London, 1996, pp. 251-261.

D. Bodamer, Catch the Wind, Civil Engineering, July 1999, pp. 50-53. 
P. -C. Aïtcin, Cement and Concrete Development From an Environmental Perspective, in Concrete Technology for a Sustainable Development in the $21^{\text {st }}$ Century, O.E. Gjørv and K. Sakai, E \& FN Spon, London, 2000, pp. 206-217.

A. Bilodeau, V. Sivasundaram, K.E. Painter and V.M. Malhotra, Durability of Concrete Incorporating High Volumes of Fly Ash from Sources in the U.S., ACI Materials Journal, Vol. 91, No. 1, 1994, pp. 3-12.

Danish Energy Association, Recommendation for Technical Approval of Offshore Wind Turbines, 2001.

J.V.M. Gómez-Soberón, Porosity of Recycled Concrete with Substitution of Recycled Aggregate: An Experimental Study, Cement and Concrete Research, Vol. 32, No. 8, 2002, pp. 1301-1311.

D.W.S. Ho, S.L. Mak and K.K. Sagoe-Crentsil, in Concrete Technology for a Sustainable Development in the $21^{\text {st }}$ Century, O.E. Gjørv and K. Sakai, E \& FN Spon, London, 2000, pp.236-245.

G.C. Hoff, Durability of Fiber Reinforced Concrete in Severe Marine Environment, Concrete Durability-Katherine and Bryant Mather International Conference, J.M. Scanlon (ed.), ACI SP-100, American Concrete Institute, Detroit, 1987, pp. 997-1041.

T.C. Holland, Sustainability of the Concrete Industry-What Should be ACI's Role?, Concrete International, Vol. 24, No. 7, 2002, pp. 35-40.

M. Jacott, C. Reed, A. Taylor and M. Winfield, Energy Use in the Cement Industry in North America: Emissions, Waste Generation and Pollution Control 1990-2001, Second North American Symposium on Assessing the Environmental Effects of Trade, 2003.

K. Kosa and A.E. Naaman, Corrosion of Steel Fiber Reinforced Concrete, ACI Materials Journal, Vol. 87, No. 1, 1998, pp. 27-37.

V.M. Malhotra, Making Concrete Greener with Fly Ash, Concrete International, Vol. 21, No. 5,1999 , pp. 61-66.

V.M. Malhotra, Role of Supplementary Cementing Materials in Reducing Greenhouse Gas Emissions, in Concrete Technology for a Sustainable Development in the $21^{\text {st }}$ Century, O.E. Gjørv and K. Sakai, E \& FN Spon, London, 2000, pp. 226-235.

V.M. Malhotra, High-Performance High-Volume Fly Ash Concrete, Concrete International, Vol. 24, No. 7, 2002, pp. 30-39.

V.M. Malhotra, M.H. Zhang and S.L.Sarkar, Manufacture of Concrete Test Panels and their Performance after Seven Years of Exposure in Arctic Marine Environment, ACI Materials Journal, Vol. 97, No. 2, 2000, pp. 99-107. 
V.M. Malhotra, M.H. Zhang, P.H. Read and J. Ryell, Long-Term Mechanical Properties and Durability Characteristics of High-Strength/High-Performance Concrete Incorporating Supplementary Cementing Materials under Outdoor Exposure Conditions, ACI Materials Journal, Vol. 97, No. 5, 2000, pp. 518-525.

P.S. Mangat and B.T. Molloy, Size Effect of Reinforcement on Corrosion Initiation, in Proceedings of the Fifth International RILEM Symposium, Lyon, September 2000, P. Rossi and G. Chanvillard (eds.), RILEM, Cachan, 2000, pp. 691-701.

P.S. Mangat and K. Gurusamy, Corrosion Resistance of Steel Fibres in Concrete Under Marine Exposure, Cement and Concrete Research, Vol. 18, No. 1, 1998, pp. 44-54.

P.K. Mehta, Concrete Technology for Sustainable Development-An Overview of Essential Elements, in Concrete Technology for a Sustainable Development in the $21^{\text {st }}$ Century, O.E. Gjørv and K. Sakai, E \& FN Spon, London, 2000, pp. 83-94.

P.K. Mehta, Reducing the Environmental Impact of Concrete, Concrete International, Vol. 23, No. 10, 2001, pp. 61-66.

P.K. Mehta, Greening of the Concrete Industry for Sustainable Development, Concrete International, Vol. 24, No. 7, 2002, pp. 23-28.

F.T. Olorunsogo and N. Padayachee, Performance of Recycled Aggregate Concrete Monitored by Durability Indexes, Cement and Concrete Research, Vol. 32, No. 2, 2002, pp. 179-185.

S.G. Park, Recycled Concrete Construction Rubble as Aggregate for New Concrete, BRANZ Study Report No. 86, 1999.

S.G. Park, Effect of Recycled Concrete Aggregate on New Concrete, BRANZ Study Report No. 101, 2001.

M. Raupach and C. Dauberschmidt, Investigations into the Critical Corrosion-Inducing Chloride Content of Steel Fibres in Artificial Concrete Pore Solution, Materials and Corrosion, Vol. 53, 2002, pp. 408-416.

K.K. Sagoe-Crentsil, T. Brown and A.H. Taylor, Performance of Concrete Made with Commercially Produced Coarse Recycled Concrete Aggregate, Cement and Concrete Research, Vol. 31, No. 5, 2001, pp. 707-712.

R.M. Salem and E.G. Burdette, Role of Chemical and Mineral Admixtures on Physical Properties and Frost-Resistance of Recycled Aggregate Concrete, ACI Materials Journal, Vol. 95, No. 5, 1998, pp. 558-563. 
A. Shayan and A. Xu, Performance and Properties of Structural Concrete Made with Recycled Concrete Aggregate, ACI Materials Journal, Vol. 100, No. 5, 2003, pp. 371380.

M. Tavakoli and P. Soroushian, Strengths of Recycled Aggregate Concrete Made Using Field-Demolished Concrete as Aggregate, ACI Materials Journal, Vol. 93, No. 2, 1996, pp. 182-190. 